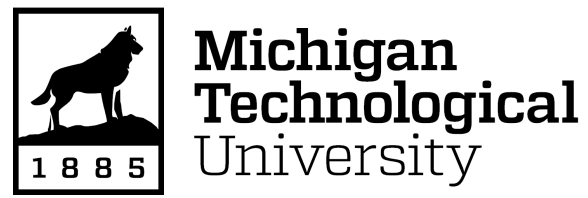

Michigan Technological University Digital Commons @ Michigan Tech

Dissertations, Master's Theses and Master's Reports

2021

\title{
Anterior cruciate ligament injury incidence across sex, sport, and level: a systematic review and meta-analysis
}

Dana Anderson

Michigan Technological University, danaa@mtu.edu

Copyright 2021 Dana Anderson

\section{Recommended Citation}

Anderson, Dana, "Anterior cruciate ligament injury incidence across sex, sport, and level: a systematic review and meta-analysis", Open Access Master's Thesis, Michigan Technological University, 2021.

https://doi.org/10.37099/mtu.dc.etdr/1265

Follow this and additional works at: https://digitalcommons.mtu.edu/etdr

Part of the Sports Medicine Commons 


\title{
ANTERIOR CRUCIATE LIGAMENT INJURY INCIDENCE ACROSS SEX, SPORT, AND LEVEL: A SYSTEMATIC REVIEW AND META-ANALYSIS
}

\author{
By \\ Dana L. Anderson \\ A THESIS \\ Submitted in partial fulfillment of the requirements for the degree of \\ MASTER OF SCIENCE \\ In Biological Sciences
}

MICHIGAN TECHNOLOGICAL UNIVERSITY

2021

(C) 2021 Dana L. Anderson 
This thesis has been approved in partial fulfillment of the requirements for the Degree of MASTER OF SCIENCE in Biological Sciences.

Department of Biological Sciences

Thesis Co-Advisor: $\quad$ Erich J. Petushek, PhD

Thesis Co-Advisor: $\quad$ John J. Durocher, PhD

Committee Member: $\quad$ Brigitte Morin, $M S$

Committee Member: $\quad$ Robert A. Larson, PhD

Department Chair: Chandrashekhar P. Joshi, PhD 


\section{Table of Contents}

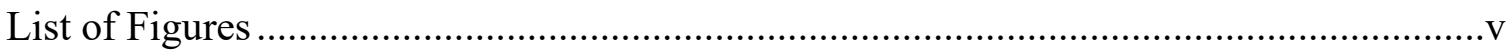

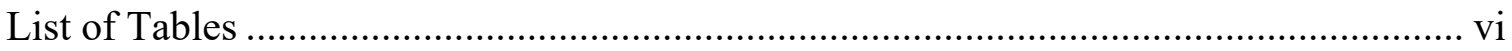

Acknowledgements................................................................................................ vii

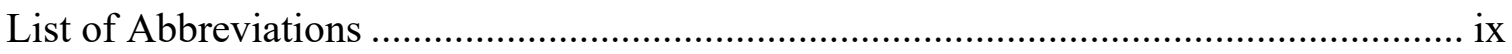

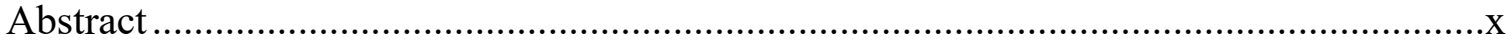

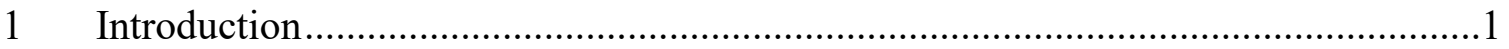

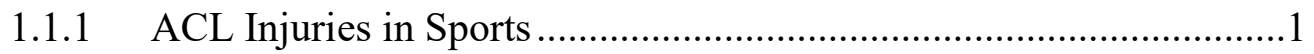

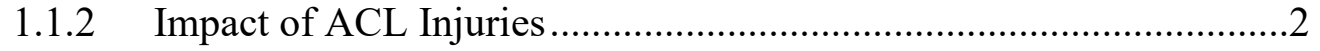

1.1.3 Injury Prevention Neuromuscular Training …….................................

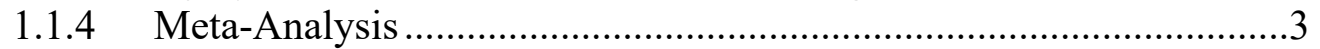

1.1.5 Current Limitations of Other Studies...............................................

1.1.6 Purpose of the Study ........................................................................

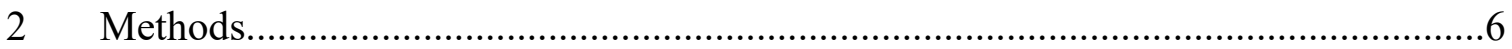

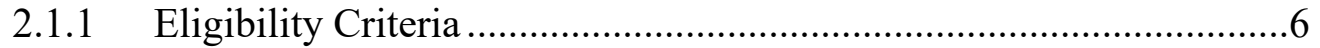

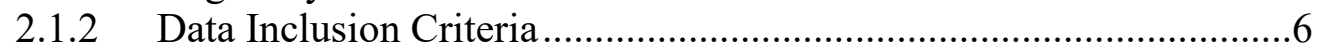

2.1.3 Data Extraction and Analysis..........................................................

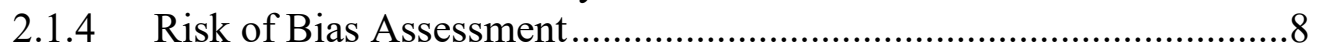

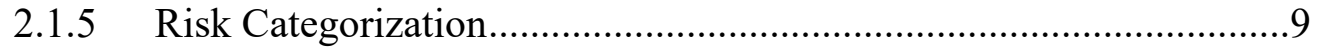

2.1.6 Statistical Analysis...................................................................... 10

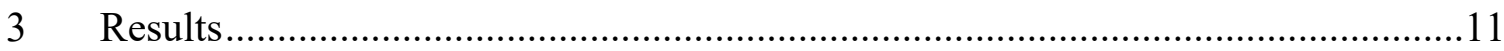

3.1.1 Risk of Bias Assessment................................................................13

3.1.2 Results by Sport Type/Level/Sex.................................................14

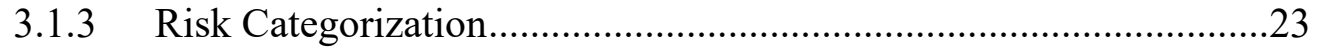

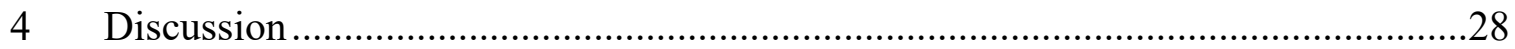

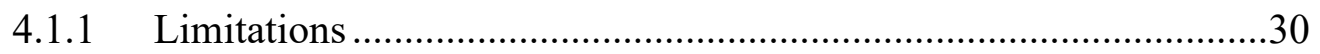

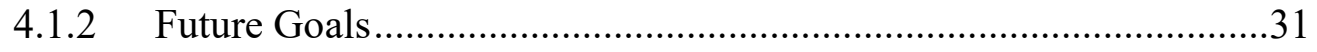

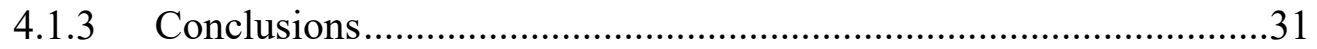

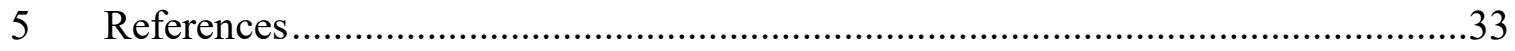

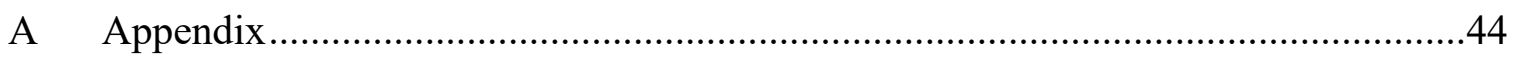

A.1 Table of Data Extracted for all Studies Based on Sport Type, Level and Sex 44 
A.2 Table of the Results/Scores of the Risk of Bias Assessment .......................52

A.3 Figure of the JBI Critical Appraisal Checklist ..............................................56 


\section{List of Figures}

Figure 1: Flowchart summary of the article/literature screening process and review ......12

Figure 2: Risk of Bias Assessment Score Proportion ............................................. 13

Figure 3: Forest plot for the combined injury rate of anterior cruciate ligament injury in male and female sports, across each level ...........................................................15

Figure A.3.1: JBI Critical Appraisal Checklist for Studies Reporting Prevalence Data........................................................(Appendix A.3) 56 


\section{List of Tables}

Table 1: Combined injury rate of anterior cruciate ligament injuries and their associated level of risk

Table A.1.1: Data Extracted From Each Study................................... (Appendix A.1) 44

Table A.2.1: Results of the Risk of Bias Assesment Using The Joanna Briggs Institute Critical Apprasial tools for use in JBI Systematic Reviews ....... (Appendix A.2) 52 


\section{Acknowledgements}

The completion of my master's thesis project could not have been achieved without the support and guidance from many individuals. I would like to acknowledge those who deserve special recognition. First and foremost, I would like to thank and praise God, who provided me with countless blessings and opportunities to accomplish my thesis. Even when life proved difficult you were always watching over me and were the friend and Father whom I could continually pray to.

I would like to recognize the Department of Biological Sciences for their support toward obtaining my master's degree and to my Advisor Dr. Erich Petushek. Without you, my research would not have been possible. You not only shared your extensive knowledge of cognitive sciences with me, but were also very flexible and versatile, from hopping on random zoom calls in a moment's notice, to helping me decipher endless amounts of data and spreadsheets. Thank you for providing me with practical suggestions and allowing me to conduct research on your behalf. I would also like to express my gratitude to my co-advisor, Dr. John Durocher. Even amid transferring Universities and a global pandemic, you tried your best to ensure I had adequate resources to continue with my research project. From finding me a new Advisor to always answering my longwinded emails. I am grateful for the opportunity to have developed my skills and learn how to advocate for myself but leaning on you when I needed support. I would also like to recognize Brigitte Morin and Dr. Robert Larson for serving as valuable personnel on my committee, who helped finalize my thesis work. 
My deepest gratitude is expressed to my friends and family, who have encouraged me during this journey of obtaining my master's degree. In particular, I would like to thank my parents, Jody and Craig, who have supported me throughout my college career and sacrificed themselves, in order to get me where I am today. No number of words could express the love and admiration I have for you, because you always put the needs of your kids first. I would also like to thank my siblings who have continually inspired me and pushed me to become the best version of myself. Most notably I want to extend my sincere gratitude to my twin sister, Lia. She is my rock, the person I could always turn to for help and consolation and without her by my side, my life would have seemed impossible. I would also like to express my true appreciation for the unwavering encouragement from my fiancé, Noah, who was one of my biggest cheerleaders and never allowed me to give up.

I would also like to recognize my church community at Evangel for allowing me to feel at home and providing an outlet with the worship team and pre-school children's ministry during these stressful times. Lastly, I would like to acknowledge the many organizations that I was a part of throughout college, from Michigan Technological Emergency Medical Services to my sorority and Sisters of Theta Chi Epsilon. Without this amazing community of people surrounding me, none of this would be possible. 


\section{List of Abbreviations}

ACL Anterior Cruciate Ligament

AE Athlete Exposure

CI Confidence Interval

PRISMA Preferred Reporting Items for Systematic Reviews and Meta-Analyses IR Injury Rate 


\section{Abstract}

Well controlled Anterior Cruciate Ligament (ACL) injury prevention neuromuscular training reduces the risk of ACL injury by $50 \%$, but despite the efficacy of these programs, ACL injury rates have not decreased. This lack of decrease in injury incidence may be due in part to limited knowledge on who is most at risk for sustaining an ACL injury, and there is no formal clinical tool available to estimate the personalized or group risk of ACL injury. The purpose of this study was to better understand what groups of athletes are most at risk of sustaining a primary ACL injury, as the first step in mitigating risk and decreasing the substantial public health and financial burden of ACL injuries. To accomplish this goal, we conducted a systematic review and meta-analysis using the Preferred Reporting Items for Systematic Reviews and Meta-Analyses (PRISMA) guidelines and through specific inclusion/exclusion criteria to analyze specific subgroupings of athletes. 7,038 studies were identified in the initial database search and 80 studies were included in the final subgroup meta-analysis. Analyses revealed that female athletes had a greater risk of ACL injury compared to male athletes. However, this project pointed out gaps in the current epidemiological prevalence of ACL injuries and the extra precaution people should take about the overgeneralization of sex and sport types for risk assessment. For example, it is well known that for sex comparable sports, females are at greater risk for ACL injury compared to males - however, the absolute risk level for various female sports is substantially low (e.g., female high school volleyball and female college lacrosse). In addition, female professional sports have overall higher ACL injury rates and prevention programs appear less effective for this group warranting 
more rigorous and targeted prevention efforts. Future studies should also utilize rigorous epidemiological approaches to assess injury rates as there are many sports, sex, and levels that do not have sufficient data to determine absolute prevalence or risk level. When more information is discovered, a personalized risk assessment tool can then be developed to then determine the most at-risk populations to allocate resources and prevention efforts to reduce the number of ACL injuries. 


\section{Introduction}

\subsubsection{ACL Injuries in Sports}

It is estimated that approximately 21 million children, between the ages of 6 and 17, in the United States participate in sports ${ }^{(50) .}$ Even with this estimation, the number of youth athletes who participate in sports is even higher, because the above number does not include the millions of children who start before the age of $6^{(50) \cdot}$ Participation in such sports is a vital component to fostering long-term health and well-being. However, with these great benefits, there are many risks and consequences involved with competitive sports. Knee injuries are the most common severe ${ }^{(22)}$ and season/career ending sport injury ${ }^{(111),}$ the majority of which are anterior cruciate ligament (ACL) injuries ${ }^{(49) .}$ The ACL is a type of cruciate ligament that is found in the front of the distal knee joint and crosses with the posterior cruciate ligament in the back, to form an " $\mathrm{X}$ ", when viewing the knee joint. The anterior cruciate ligament prevents the tibia, or shinbone, from sliding out in front of the femur, or thighbone, as well as provides rotational stability to the knee

(4). ACL injuries can vary from a sprain of the cruciate ligament to a full rupture and is regularly seen through both noncontact and contact (direct) mechanisms. Most commonly, people tend to tear, or rupture the whole ACL. On the other hand, sprains and partial tears are more unusual and may go unrecognized ${ }^{(121) .}$ About half of all injuries to the anterior cruciate ligament occur in conjunction with damage to other structures in the knee, such as meniscus or other ligaments ${ }^{(121) .}$ 


\subsubsection{Impact of ACL Injuries}

ACL injuries present a significant impact on our healthcare system. In addition to the financial burden of one ACL injury cost being approximately $\$ 38,000 \mathrm{USD}^{(63)}{ }^{\text {, there }}$ are also remarkable personal costs that arise. ACL injured athletes have a higher risk, approximately 4 times, for osteoarthritis ${ }^{(3),(76),(11),(18), \text { total knee replacement }}{ }^{(108)}$ and have impaired knee quality of life in 5-25 years ${ }^{(32)}$. There are two treatment options for an ACL injury which include nonsurgical treatments such as a brace or rehabilitation through physical therapy and/or a surgical reconstruction to restore the internal structures of the knee ${ }^{(121) .}$ Choice of treatment depends on a variety of factors such as severity of the injury, age, and activity level. Usually, people choose reconstruction if they want to return to their sport or are younger in age and want to prevent or prolong the time until arthritis could develop ${ }^{(121) .}$ When an athlete injures their ACL, they are looking at substantial recovery time of approximately one year. About $45 \%$ of injured athletes will not go back to the competitive sport (5), (6), (61) and even if return is possible, performance is likely to decrease upon return ${ }^{(61),(51) .}$

\subsubsection{Injury Prevention Neuromuscular Training}

Well controlled ACL injury prevention neuromuscular training reduces the risk of ACL injury by 50\% (from 1 in 66 to 1 in 133) (106),(107),(102), (73). Effective injury prevention training programs include landing stabilization exercises such as hopping and holding as well as lower body strengthening exercises such as lunges and hamstring

exercises ${ }^{(122) .}$ The exercises are typically done throughout the season prior to every 
practice as a warm-up activity led and supervised by coaches or sports medicine professionals. However, despite knowing the efficacy of prevention programs since 2008,

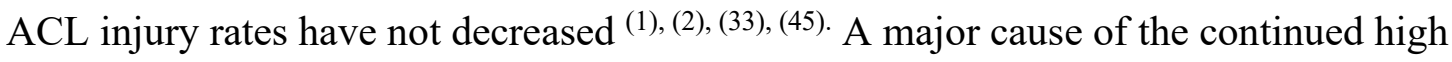
incidence is the lack of use of ACL injury prevention training, partly due to limited knowledge on who should receive this training. Certain athlete characteristics have been associated with increased ACL injury risk such as age, sport played, or sex. These various independent factors all influence the risk for ACL injury, but a more comprehensive and usable multivariate model is needed. This model will best characterize risk levels and more likely lead to sustained clinical use and implementation. Nonetheless, this knowledge is still sparse because there is no formal clinical tool available to estimate the personalized risk of ACL injury. A risk assessment program would allow physicians to recommend effective injury prevention programs and advise those around the athlete to make more informed decisions about their health and safety. Simple and accurate risk assessment would increase motivation for prevention initiatives, advance prognostic testing and focus more resources on the most vulnerable individuals and groups of athletes.

\subsubsection{Meta-Analysis}

In order to determine and compare the rates of ACL injury in female and male athletes across various sport types and levels, the conditions for the data collection must be similar. If the methods of such data collection differ, then it is not possible to compare their injury rates and thus creating a personalized risk assessment tool would be unlikely. 
Therefore, statistical analysis approaches like a meta-analysis may prove to be very useful in estimating these injury rates. A meta-analysis is the combining and analyzing of data from multiple studies, at a given time ${ }^{(65) .}$ Utilizing these methods, we can then determine the factors influencing ACL injury likelihood which will help to create a multivariate model that characterizes ACL injury risk.

\subsubsection{Current Limitations of Other Studies}

While previous meta-analyses and other studies have been conducted on the current epidemiological prevalence of ACL injuries, there were some inherent limitations within them. One such study examined the risk of sustaining ACL injuries in sports, and although information and data was detailed, the study was conflated with intervention

protocols ${ }^{(70) .}$ For example, the authors calculated injury rates by including and combining athletes that received an intervention and ones that did not - even though we know prevention programs can reduce risk by about $50 \%$. Athletes in the intervention group should have been excluded or analyzed separately to get a more accurate incidence rate. Prospective studies without an intervention component or even retrospective studies would have been more useful because investigators could use the data to answer questions about risk factors and disease outcomes instead of focusing on if the intervention programs were successful or not. Finally, while this study included a substantial number of articles ${ }^{(58)}$ in their meta-analysis, there was substantial variability in their rate estimates, and they did not try to determine the sources of this variability. Another article reported ACL injury risk within sports based upon the incidence by sex 
and sport classification ${ }^{(71) .}$ In this article there was a lack of understandable rate reporting since they studied athlete exposure (AE's) for their analyses. An athlete exposure is defined as one athlete participating in a game or practice, in which he/she is exposed to the possibility of athletic injury ${ }^{(8)}$. While this is the gold standard for epidemiological rate calculation and for comparing rates, it is hard to understand what the values actually mean from an absolute risk perspective. Upon analyzing and deciphering numerous other articles, we recognized common gaps of knowledge that needed to be addressed. This included things such as significant heterogeneity, which is the increased variability in rates due to diverse groups studied; or focusing on sex differences in many of the studies, which researchers cannot control. We also noticed that it is not known where there is prevalence data missing or where we need to conduct more observational studies to determine injury rates. Lastly there was a lack of translation of data and findings into usable tools and information for the application of future studies and research.

\subsubsection{Purpose of the Study}

The purpose of this systematic review and meta-analysis was to create a groupbased risk assessment tool for athletes by determining the absolute risk level of sustaining an ACL injury across known athlete groups. A secondary aim was to shed light on the sports (sex and levels) where more epidemiological prevalence data are needed. 


\section{Methods}

We followed the Preferred Reporting Items for Systematic Reviews and MetaAnalyses (PRIMSA) guidelines when conducting this systematic review and metaanalysis ${ }^{(81)}$.

\subsubsection{Eligibility Criteria}

A literature search was performed with the electronic databases of PubMed and EBS-Cohost (CINAHL Plus and MEDLINE) on April 20, 2021. A keyword search was conducted with a combination of keywords involving Anterior Cruciate Ligament Injuries AND Epidemiology OR Incidence OR Prevalence AND tear OR rupture. The search was limited to articles published in the English language and all participants were humans. Publication details from all studies identified as eligible were exported to bibliographic software (Endnote X9; Clarivate Analytics, Philadelphia, PA).

\subsubsection{Data Inclusion Criteria}

Given the large number of studies identified, a single author (D.L.A.) performed the initial screening of articles for inclusion. Articles were first screened by title, next by abstract and then by reading of the study according to the inclusion and exclusion criteria. The following inclusion criteria was applied: (1) Research conducted in athletes playing in organized sports, (2) Total number of ACL injuries (both noncontact and contact in nature) and total number individuals (non-injured) in the population were recorded. Studies were particularly excluded if: (1) secondary ACL injury was detailed, (2) total 
population was not identified, (3) mentioned strictly ACL reconstruction, not denoting ACL injuries, (4) multi-sport athletes, and (5) no differentiation between male and female athletes. Any discrepancies were discussed and resolved with a second author (E.J.P). During the literature search, cross-referencing was performed when studies that that met inclusion criteria cited other studies.

\subsubsection{Data Extraction and Analysis}

Each article was analyzed for the following information: year of publication, type of study, the studies observational time-period, the number of ACL injuries, sample characteristics including type of sport, participation level, mechanism of injury (noncontact vs contact), sex, and total participants. Due to sports being played outside the United States, some levels were hard to establish as uniform. Thus, we grouped semiprofessional and collegiate teams together and labeled them as collegiate. The reported person-time unit was not uniform across studies. Thus, to establish a more common metric of comparison we calculated the combined injury rate (IR) for ACL's by taking the absolute value of ACL injuries per year and dividing it by the absolute value of noninjured ACLs. For studies in which the number of ACL injuries could not be established, or total participation was not listed, we emailed authors to gather that data. If they could not provide that data or did not respond, the study was excluded from the meta-analysis. Discrepancies between classifications or values were discussed and resolved between the authors (D.L.A. and E.J.P). 


\subsubsection{Risk of Bias Assessment}

The risk of bias assessment was conducted using the Joanna Briggs Institute Critical Appraisal tool for use in JBI Systematic Reviews ${ }^{(72) .}$ This tool assessed characteristics such as if the participants were recruited in an appropriate way, if the sample size was adequate, were there valid, and standard methods for all subjects, and if there was appropriate statistical analysis. For each study, the item on the checklist was either answered with a "yes", "no", "unclear" or "not applicable". The full checklist can be seen in Figure A.3.1 (Appendix A.3). Out of a checklist of nine items, an overall appraisal was given to the studies on whether to include them in our analysis or not. If criteria were met, and an item was labeled with a "yes" it was scored as 1 . If criteria were not met, and an item was labeled with an "unclear" or "no" it was scored as a 0 . The maximum score possible was 9. Any discrepancies in scoring were discussed by the two authors (D.L.A. and E.J.P). The studies that received a total score of 8 and above were given a high-quality rating. The studies that received a total score of 7 out of $9(77 \%)$ was given a moderate quality rating. Those that had a total score of 6 out of $9(66 \%)$ was given a moderate/low quality rating. The studies that received a total score of less than or equal to 5 were deemed to be of low quality.

Using the checklist described above, proved to be difficult for some of the studies. As such we modified and added to our criteria for specific questions. For question 3 when it asked if the sample size was adequate, we added a clause that if a study had equal to or greater than 10 ACL injuries, or events, then the sample size was deemed sufficient ${ }^{(23) \text {. }}$ 
This was then labeled with a "yes". If a study particularly examined at intervention techniques, we based our numbers only on the control group, and not each intervention

group. Another question we had to pay close attention to, was question 9, which asked if the response rate of the study was adequate, and if not, was the low response rate managed appropriately? Many of the studies did not provide a response rate, and when they did it was hard to normalize what was deemed sufficient. If they did not provide a response rate, they were given the title, "unclear". When information was given about the rate of response, we decided that no more than $30 \%$ dropout (or $70 \%$ response rate) was considered adequate and could be labeled with a "yes".

\subsubsection{Risk Categorization}

To assign a level of risk to the athlete populations, we ordered the combined meta-analytic injury rate of the individual studies and created three groups (low, moderate, and high). To determine the risk category cut off points, we divided the highest rate by three. Since the rates toward the top of the list included studies with few ACL injuries (e.g., less than 10), thus an imprecise estimate, we chose the rate that included more than 10 injuries as the highest rate to divide by. This corresponded with Male Professional Football for a combined injury rate of 0.030 and then dividing it by three to get a value of 0.010 . The lowest combined injury rate was 0 and this was the starting range for the low-risk category. To get the top value of the moderate-risk level 0.010 was added to itself to get a value of 0.020 . The ranges for each level of risk are as follows: low risk $=0-0.010$, moderate risk $=0.010-0.020$, high risk $=0.020>0.030$. 


\subsubsection{Statistical Analysis}

The primary outcome of interest for the analysis of our data was the ACL incidence rate per season, by using both univariate subgroup and meta-analysis techniques. Specifically, a random-effects model (using restricted maximum likelihood estimators) was used to calculate the incidence rates per season and statistical parameters such as 95\% Confidence Intervals (CI) for the various sport characteristics. For univariate comparisons, only the subgroups defining the sport across each level and sex, with at least two studies $(\mathrm{k} \geq 2)$ were included in the analysis. All statistical analyses and calculations were performed by use of the packages metafor ${ }^{(114)}$ and meta ${ }^{(10)}$ with the statistical software environment R (RStudio Version, 1.4.1103, the R Foundation for Statistical Computing). 


\section{Results}

The electronic literature search yielded 7038 studies for initial review. 6980 were specifically flagged from the PubMed database, and 58 studies from the Montalvo metaanalysis ${ }^{(70)}$ were included in the total number of 7038 studies. Records were removed before screening if the species were not human $(\mathrm{n}=1168)$ or not recorded in English $(n=280)$ leaving a total of 5590 studies. We screened titles and abstracts for mentions of the specific keywords and 3630 studies were excluded for lack of relevance to our research. 88 studies could not be found or retrieved, leaving us with a remaining 1872 studies. Next our inclusion and exclusion criteria were applied, which removed 1700 studies, with a new total of 172 studies. These remaining 172 studies were manually cross-referenced, contacted the corresponding authors as needed and excluded 92 studies. The reason for these exclusions were, multi-sport athletes, or not delineating between male and female sexes. At the end of the search, a total of 80 studies were included in our meta-analysis. A flowchart of the literature screening process and review is presented in Figure 1 (see below). 


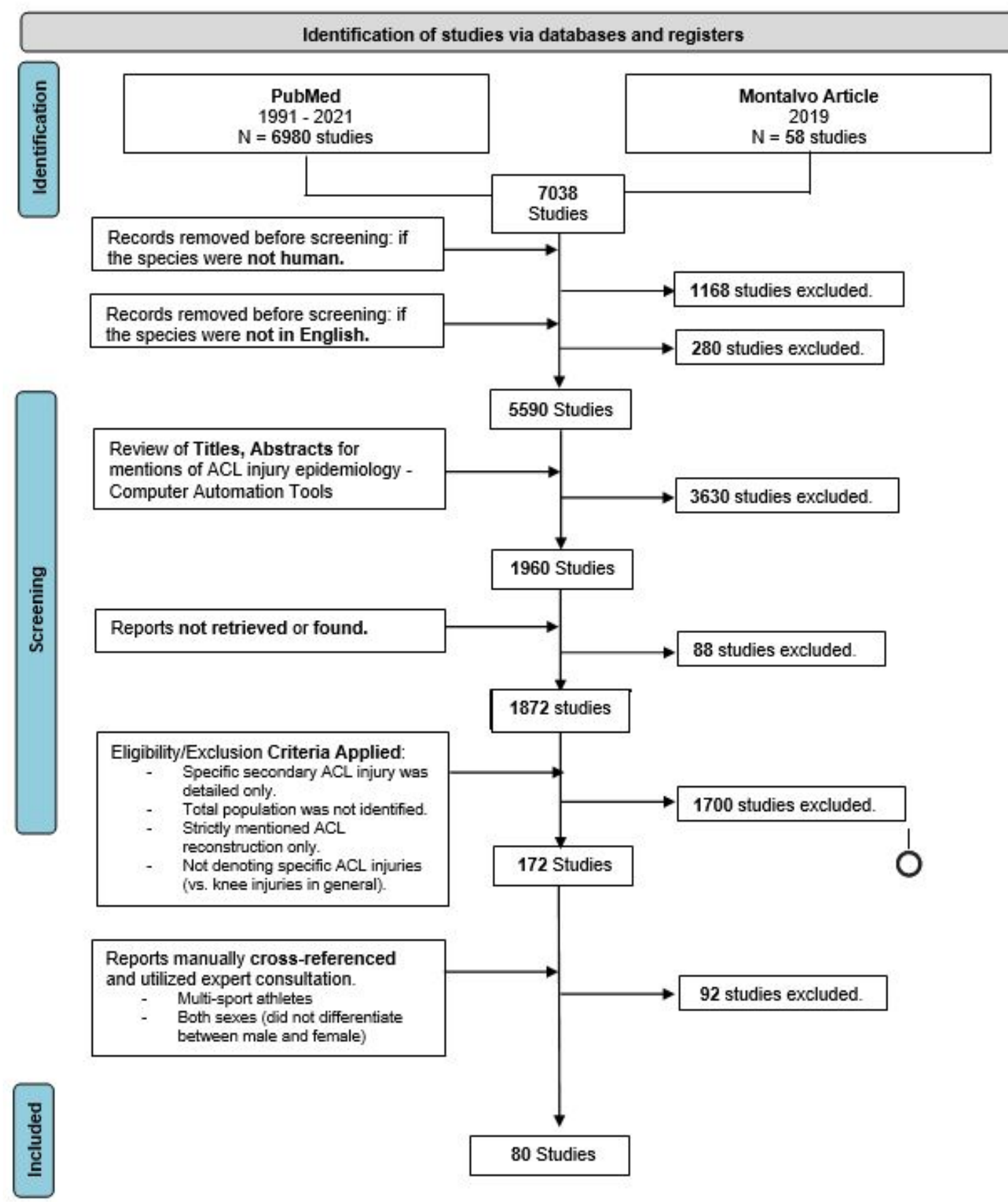

Figure 1: Flowchart summary of the article/literature screening process and review 


\subsubsection{Risk of Bias Assessment}

The results of the risk of bias assessment can be seen in Figure 2 (or see Appendix A.2, for a complete list of answers and scores). There were 35 studies out of 80 total studies that received a perfect score of 9 out of 9 points for a proportion of $44 \%$. There were 32 studies out of a total of 80 studies that had a score of 8 out of 9 points for a proportion of $40 \%$. There were 11 studies out of a total of 80 studies that received a score of 7 out of 9 points for a proportion of $14 \%$. Lastly there were 2 studies out of a total of 80 studies that had a score of 6 out of 9 points for a proportion of $2 \%$.

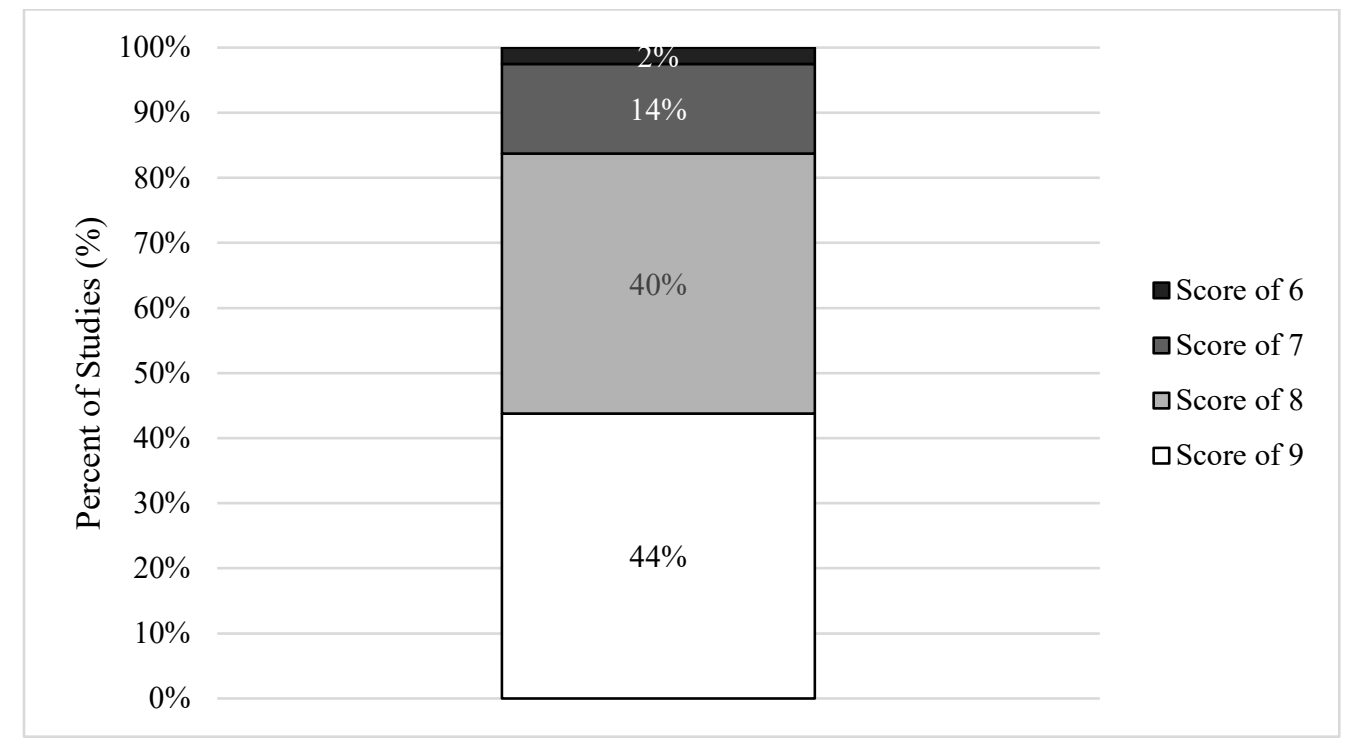

Figure 2: Risk of Bias Assessment Score Proportion ${ }^{1}$

\footnotetext{
${ }^{1}$ The risk of bias assessment score ranges from a perfect score of 9 to a score of 6 for these specific articles - the lowest possible scores would be 0 .
} 


\subsubsection{Results by Sport Type/Level/Sex}

Figure 3 shows an overview of the data for the combined meta-analytic ACL injury rate in male and female sports, across each level for subgroups that included more than 1 study (e.g., $k>1$ ). The studies included in each of the group rate estimates are included in Table A.1.1 (Appendix A.1)

\section{Alpine Skiing}

There was no data for youth or collegiate alpine skiing teams for either sex identified through our search criteria. There was a total of 2 studies $(k=2)$ found that looked at ACL injury rates in female high school alpine skiers. For this subgroup there was a sum of 5 ACL injuries per season out of 303 athletes and their combined injury rate was $0.018[0.0058,0.053]$. There was a total of 2 studies $(k=2)$ found that investigated ACL injury rates in male high school alpine skiers. For this subgroup there was a sum of 5 ACL injuries per season out of 382 athletes, and their combined injury rate was 0.014 $[0.0057,0.032]$. There was a total of 4 studies $(\mathrm{k}=4)$ found that explored ACL injury rates in female professional alpine skiers. For this subgroup there was a sum of $10 \mathrm{ACL}$ injuries per season out of 1,116 athletes and a combined injury rate of $0.010[0.0047$, 0.023]. There was a total of 4 studies $(\mathrm{k}=4)$ found for male professional alpine skiers. From this subgroup there was a sum of 10 ACL injuries per season out of 1,522 athletes, for a combined injury rate of $0.0071[0.0038,0.013]$. 


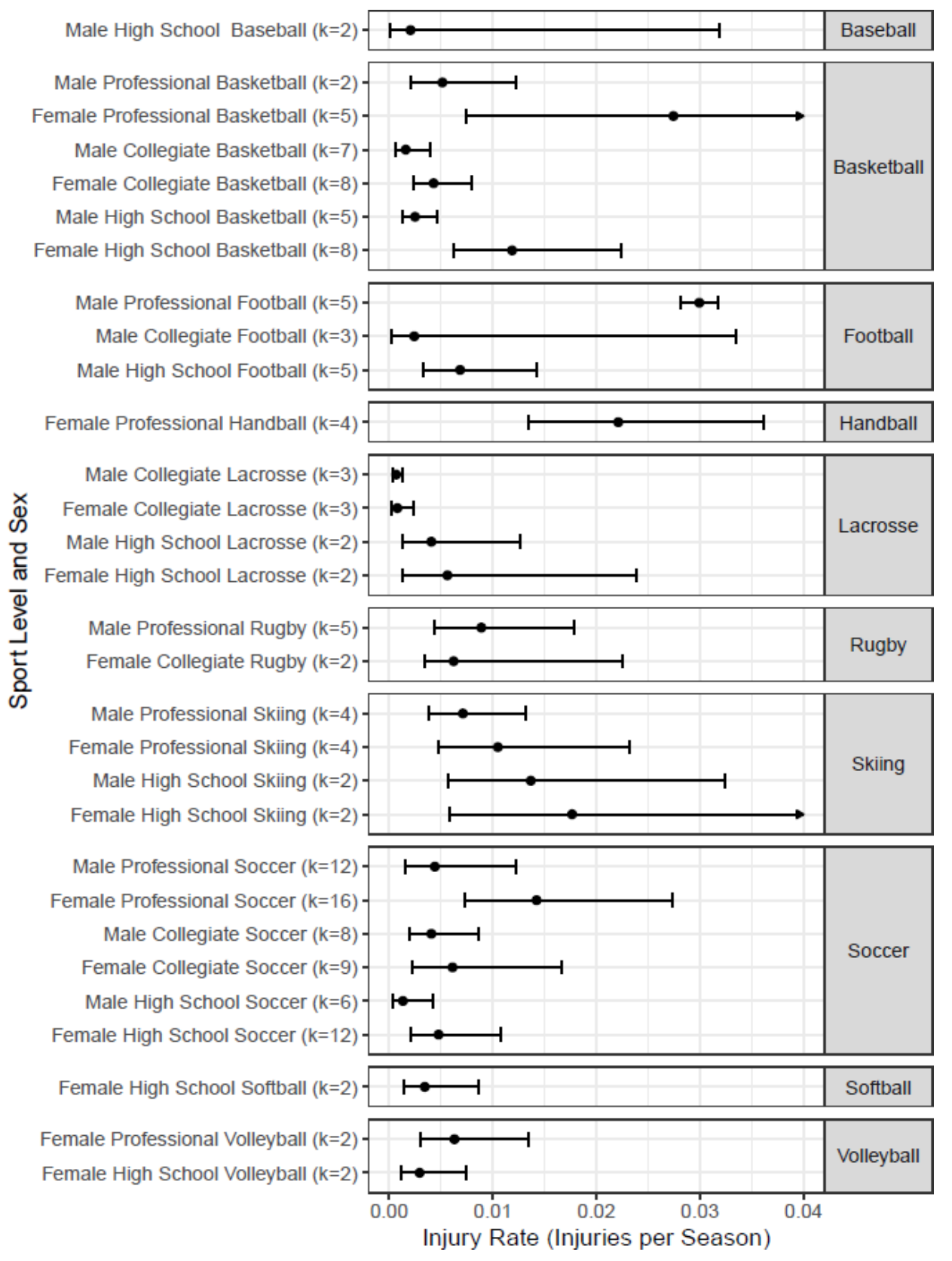

Figure 3: Forest plot for the combined injury rate of anterior cruciate ligament injury in male and female sports, across each level. ${ }^{2}$

${ }^{2}$ Error bars represent the $95 \%$ confidence intervals (CI's). 


\section{Basketball}

There was no data for youth basketball teams for either sex identified through our search criteria. There was a total of 8 studies $(k=8)$ found that researched ACL injury rates in female high school basketball players. For this subgroup there was a sum of 66 ACL injuries per season out of 6,936 athletes and their combined injury rate was 0.012 $[0.0063,0.022]$. There was a total of 5 studies $(k=5)$ found that inspected ACL injury rates in male high school basketball players. For this subgroup there was a sum of 12 ACL injuries per season out of 5,821 athletes and their combined injury rate was 0.0025 $[0.0013,0.0047]$. There was a total of 8 studies $(k=8)$ found that examined ACL injury rates in female collegiate basketball players. For this subgroup there was a sum of 196 ACL injuries per season out of 72,391 athletes and their combined injury rate was 0.0043 $[0.0023,0.0079]$. There was a total of 7 studies $(k=7)$ found that researched ACL injury rates in male collegiate basketball players. For this subgroup there was a sum of $58 \mathrm{ACL}$ injuries per season out of 70,087 athletes and their combined injury rate was 0.0016 $[0.00064,0.0040]$. There was a total of 5 studies $(k=5)$ found that observed ACL injury rates in female professional basketball players. For this subgroup there was a sum of 21 ACL injuries per season out of 1,066 athletes and their combined injury rate was 0.027 $[0.0075,0.096]$. There was a total of 2 studies $(\mathrm{k}=2)$ found that studied ACL injury rates in male professional basketball players. For this subgroup there was a sum of 5 ACL injuries per season out of 1,002 and their combined injury rate was 0.0051 [0.0021, $0.012]$. 


\section{Floorball}

There was no data for youth or collegiate floorball teams for either sex identified through our search criteria. There was also no information found for male professional floorball teams. There was 1 study found $(\mathrm{k}=1)$ that surveyed ACL injury rates in female high school floorball players. For this subgroup there was a sum of 3 ACL injuries per season out of 72 athletes, for an injury rate of $0.042[0.014,0.12]$. There was 1 study $(\mathrm{k}=1)$ found that inspected ACL injury rates in female professional floorball players. For this subgroup there was a sum of $=3$ ACL injuries per season out of 198 athletes for an injury rate of $0.015[0.0049,0.050]$.

\section{Football}

There was no data identified for female football teams at any level through our search criteria. There was also no information found for youth for either sex. There was a total of 5 studies $(\mathrm{k}=5)$ found that examined ACL injury rates in male high school football players. For this subgroup there was a sum of 113 ACL injuries per season out of 14,465 athletes and their combined injury rate was $0.0068[0.0033,0.014]$. There was a total of 3 studies $(k=3)$ found that researched ACL injury rates in male collegiate football players. For this subgroup there was a sum of 82 ACL injuries per season out of 314,2017 athletes and their combined injury rate was 0.0024 [0.00017, 0.033]. There was a 1 study $(\mathrm{k}=1)$ found that explored ACL injury rates in male professional football players. This study was a systematic review/data validation study and as such contained 5 individual studies in it that we drew data from. For this subgroup there was an average of 57 ACL 
injuries per season out of 1895 athletes and their combined injury rate was $0.030[0.025$, $0.036]$.

\section{Handball}

There was no data for high school or collegiate teams across male handball identified through our search criteria. There was also no information found for youth handball teams for either sex. There was 1 study $(\mathrm{k}=1)$ found that examined ACL injury rates in female high school handball players. For this subgroup there was a sum of $4 \mathrm{ACL}$ injuries per season out of 100 athletes, for an injury rate of $0.04[0.015,0.10]$. There was 1 study $(\mathrm{k}=1)$ found that studied ACL injury rates in female collegiate handball players. For this subgroup there was a sum of 5 ACL injuries per season our of 137 athletes, for an injury rate of $0.0365[0.015,0.085]$. There were 4 studies $(k=4)$ found that surveyed ACL injury rates in female professional handball players. For this subgroup there was a sum of 43 ACL injuries out of 1,786 athletes and their combined injury rate was 0.022 $[0.013,0.036]$. There was 1 study $(\mathrm{k}=1)$ found that inspected ACL injury rates in male professional handball players. For this subgroup there was a sum of 4 ACL injuries per season out of 182 athletes, for an injury rate of 0.022 [0.0083, 0.057].

\section{Ice Hockey}

There was no data for youth or high school ice hockey teams for either sex, identified through our search criteria. There was also no information found for female professional ice hockey players. There was 1 study $(\mathrm{k}=1)$ that looked at ACL injury rates 
in female collegiate ice hockey players. For this subgroup there was 1 ACL injury per season out 1,019 athletes, for an injury rate of $0.00098[0.00014,0.0069]$. Another study $(\mathrm{k}=1)$ examined ACL injury rates in male collegiate ice hockey players. For this subgroup there was a sum of $3 \mathrm{ACL}$ injuries per season out of 2,117 athletes for an injury rate of $0.0014[0.00046,0.0044]$. Finally, another manuscript reported $(\mathrm{k}=1)$ reported ACL injury rates in male professional ice hockey players. For this subgroup there was a sum of 7 ACL injuries per season out of 2,081 athletes, for an injury rate of 0.0034 [0.0016, $0.0070]$.

\section{Lacrosse}

There was no data for youth or professional lacrosse teams for either sex, identified through our search criteria. There was a total of 2 studies $(k=2)$ found that inspected ACL injury rates in female high school lacrosse players. For this subgroup there was a sum of $8 \mathrm{ACL}$ injuries per season out of 1,408 athletes for and their combined injury rate was $0.0056[0.0013,0.024]$. There was a total of 2 studies $(\mathrm{k}=2)$ found that researched ACL injury rates in male high school lacrosse players. For this subgroup there was a sum of $6 \mathrm{ACL}$ injuries per season out of 1,594 athletes and their combined injury rate was $0.0041[0.0013,0.013]$. There was a total of 3 studies $(\mathrm{k}=3)$ found that reported ACL injury rates in female collegiate lacrosse players. For this subgroup there was a sum of 14 ACL injuries per season out of 29,158 athletes and their combined injury rate was $0.00078[0.00026,0.0023]$. There was a total of 3 studies $(k=3)$ found that studied ACL injury rates in male collegiate lacrosse players. For this subgroup there was a sum of 15 
ACL injuries per season out of 26,049 athletes and their combined injury rate was $0.00066[0.00035,0.0013]$.

\section{Soccer}

There was 1 study $(\mathrm{k}=1)$ found that looked at ACL injury rates in male recreational soccer. For this subgroup there was a sum of 16 ACL injuries per season out of 1,022 athletes, for an injury rate of 0.016 [0.009, 0.025]. There was a total of 12 studies $(\mathrm{k}=12)$ found that explored ACL injuries in female high school soccer. For this subgroup there was a sum of 149 ACL injuries per season out of 156,502 athletes and their combined injury rate was $0.0048[0.0021,0.011]$. There was a total of 6 studies $(k=6)$ found that looked at ACL injury rates in male high school soccer. For this subgroup there was a sum of 299 ACL injuries per season out of 717,360 athletes and their combined injury rate was 0.0013 [0.00041, 0.0042]. There was a total of 9 studies $(k=9)$ found that examined ACL injuries in female collegiate soccer. For this subgroup there was a sum of 169 ACL injuries per season out of 96,400 athletes and their combined injury rate was $0.0061[0.0022,0.017]$. There was a total of 8 studies $(k=8)$ found that researched ACL injury rates in male collegiate soccer. For this subgroup there was a sum of 117 ACL injuries per season out of 111,818 athletes and their combined injury rate was $0.0041[0.0019,0.0086]$. There was a total of 16 studies $(k=16)$ found that investigated ACL injury rates in female professional soccer. For this subgroup there was a sum of 168 ACL injuries per season out of 42,730 athletes and their combined injury rate was $0.0014[0.0073,0.027]$. There was a total of 12 studies $(\mathrm{k}=12)$ found that 
reviewed ACL injury rates in male professional soccer. For this subgroup there was a sum of 433 ACL injuries per season out of 328,609 athletes and their combined injury rate was $0.0044[0.0016,0.012]$.

\section{Softball and Baseball}

There was no data for youth or professional softball and baseball teams for either sex, identified through our search criteria. There were 2 studies $(\mathrm{k}=2)$ found that reported ACL injury rates in female high school softball players. For this subgroup there was 4 ACL injuries per season out of 3,556 athletes and their combined injury rate was 0.0034 $[0.0014,0.0086]$. There were 2 studies $(\mathrm{k}=2)$ found that examined ACL injury rates in male high school baseball players. For this subgroup there was 2 ACL injuries per season out of 4,398 athletes and their combined injury rate was $0.0021[0.00013,0.032]$. There was 1 study $(k=1)$ found that explored ACL injury rates in female collegiate softball players. For this subgroup there was 2 ACL injuries per season out of 2,598 athletes, for an injury rate of $0.020[0.0049,0.075]$.

\section{Rugby}

There was no data for female high school rugby teams or female professional rugby teams identified through our search criteria. There was also no information found for youth rugby teams for either sex. There was 1 study $(k=1)$ found that looked at ACL injury rates in male high school rugby players. For this subgroup there was 1 ACL injury per season out of 289 athletes, for an injury rate of 0.0035 [0.00049, 0.024]. There were 2 
studies $(\mathrm{k}=2)$ found that studied ACL injury rates in female collegiate rugby players. For this subgroup there was a sum of 7 ACL injuries per season out of 923 athletes and their combined injury rate was $0.00621[0.0034,0.023]$. There was 1 study $(k=1)$ that inspected ACL injury rates in male collegiate rugby players. For this subgroup there was 1 ACL injury per season out of 119 athletes, for an injury rate of 0.0084 [0.0012, 0.057]. There was a total of 5 studies $(\mathrm{k}=5)$ found that researched ACL injury rates in male professional rugby players. For this subgroup there was a sum of $12 \mathrm{ACL}$ injuries per season out of 1,736 athletes and their combined injury rate was 0.0089 [0.0044, 0.018].

\section{Volleyball}

There was no data identified for male volleyball teams at any level through our search criteria. There was also no information found for youth volleyball teams for either sex. There was a total of 2 studies $(\mathrm{k}=2)$ found that examined ACL injury rates in female high school volleyball players. For this subgroup there was a sum of 4 ACL injuries per season out of 1,577 athletes and their combined injury rate was 0.0029 [0.0012, 0.0074]. There was a total of 2 studies $(\mathrm{k}=2)$ found that reported ACL injury rates in female professional volleyball players. For this subgroup there was a sum of $10 \mathrm{ACL}$ injuries per season out of 1,764 athletes and their combined injury rate was $0.0063[0.0030,0.013]$.

\section{Other Sports}

The sports that only had one study $(\mathrm{k}=1)$ can been seen in Table A.1.1 (Appendix A.1). These included High School Handball, Collegiate Handball, Professional Netball, 
Collegiate Ice Hockey, Professional Ice Hockey, Youth Soccer, Recreational Soccer, Collegiate Softball and Baseball, High School Rugby, and High School Wrestling.

There were several studies that included various levels of sports, delineated by sex that had 0 events or ACL injuries. They were excluded in our individual metaanalysis divided by subgroup because they are not a reliable estimate but can still be seen in Table A.1.1 (A.1. Appendix). These excluded subgroups are as follows: Professional Female Ballet, Professional Male Ballet, Male Professional Dance, Female Collegiate Field Hockey, Male High School Floorball, Male High School Floorball, Female Collegiate, Gymnastics, Male Collegiate Gymnastics, Female Collegiate Volleyball.

\subsubsection{Risk Categorization}

Female High School Floorball, Female High School Handball and Female Collegiate Handball had a high level of risk associated with them; however, these categorizations could be due to imprecise rates. Male Professional Football, Female Professional Basketball, Female Youth Soccer, Female Professional handball, and Male Professional Handball had a high level of risk associated with them. Although these sport types were the highest risk, it is worth mentioning that some of the confidence intervals are wide due to the low number of injuries. Therefore, these point estimates should be viewed with caution. For a list and values of the moderate-risk and low-risk sports, please refer to Table 1 (see below). 


\begin{tabular}{|c|c|c|c|c|c|}
\hline Level, Sex & $\begin{array}{l}\text { Combined } \\
\text { Injury Rate }\end{array}$ & $\begin{array}{c}95 \% \\
\text { Confidence } \\
\text { Interval } \\
\text { (Lower } \\
\text { Bound) }\end{array}$ & $\begin{array}{c}95 \% \\
\text { Confidence } \\
\text { Interval } \\
\text { (Upper } \\
\text { Bound) }\end{array}$ & $\begin{array}{c}\text { Level of } \\
\text { Risk }^{3}\end{array}$ & $\begin{array}{c}\text { Total } \\
\text { Number of } \\
\text { Injuries }\end{array}$ \\
\hline $\begin{array}{c}\text { Female } \\
\text { High School } \\
\text { Floorball }\end{array}$ & 0.042 & 0.0087 & 0.12 & High & 3 \\
\hline $\begin{array}{c}\text { Female } \\
\text { High School } \\
\text { Handball }\end{array}$ & 0.040 & 0.011 & 0.099 & High & 4 \\
\hline $\begin{array}{c}\text { Female } \\
\text { Collegiate } \\
\text { Handball }\end{array}$ & 0.037 & 0.012 & 0.083 & High & 5 \\
\hline $\begin{array}{c}\text { Male } \\
\text { Professional } \\
\text { Football }\end{array}$ & 0.030 & 0.028 & 0.032 & High & 915 \\
\hline $\begin{array}{c}\text { Female } \\
\text { Professional } \\
\text { Basketball }\end{array}$ & 0.027 & 0.0075 & 0.0956 & High & 14 \\
\hline $\begin{array}{c}\text { Female } \\
\text { Professional } \\
\text { Handball }\end{array}$ & 0.022 & 0.013 & 0.036 & High & 43 \\
\hline $\begin{array}{c}\text { Male } \\
\text { Professional } \\
\text { Handball }\end{array}$ & 0.022 & 0.0060 & 0.055 & High & 4 \\
\hline $\begin{array}{c}\text { Female } \\
\text { High School } \\
\text { Alpine } \\
\text { Skiing } \\
\end{array}$ & 0.018 & 0.0058 & 0.053 & Moderate & 5 \\
\hline $\begin{array}{c}\text { Female } \\
\text { Professional } \\
\text { Dance }\end{array}$ & 0.018 & 0.0021 & 0.060 & Moderate & 2 \\
\hline $\begin{array}{c}\text { Male } \\
\text { Recreational } \\
\text { Soccer }\end{array}$ & 0.016 & 0.0090 & 0.025 & Moderate & 16 \\
\hline $\begin{array}{l}\text { Female } \\
\text { Professional } \\
\text { Floorball }\end{array}$ & 0.015 & 0.0031 & 0.044 & Moderate & 3 \\
\hline
\end{tabular}

\footnotetext{
${ }^{3}$ Low risk combined injury rate range $=0-0.010$. Moderate risk combined injury rate range $=0.010-0.020$.
} High risk combined injury rate range $=0.020>0.030$. 


\begin{tabular}{|c|c|c|c|c|c|}
\hline $\begin{array}{c}\text { Female } \\
\text { Professional } \\
\text { Soccer }\end{array}$ & $\mathbf{0 . 0 1 4}$ & 0.0073 & 0.027 & Moderate & 168 \\
\hline $\begin{array}{c}\text { Male High } \\
\text { School } \\
\text { Alpine } \\
\text { Skiing }\end{array}$ & $\mathbf{0 . 0 1 4}$ & 0.0057 & 0.032 & Moderate & 5 \\
\hline $\begin{array}{c}\text { Female } \\
\text { High School } \\
\text { Basketball }\end{array}$ & $\mathbf{0 . 0 1 2}$ & 0.0063 & 0.022 & Moderate & 66 \\
\hline $\begin{array}{c}\text { Female } \\
\text { Professional } \\
\text { Alpine } \\
\text { Skiing }\end{array}$ & $\mathbf{0 . 0 1 0}$ & 0.0047 & 0.023 & Moderate & 10 \\
\hline $\begin{array}{c}\text { Male } \\
\text { Professional } \\
\text { Rugby }\end{array}$ & $\mathbf{0 . 0 0 8 9}$ & 0.0044 & 0.018 & Low & 12 \\
\hline $\begin{array}{c}\text { Male } \\
\text { Collegiate } \\
\text { Rugby }\end{array}$ & $\mathbf{0 . 0 0 8 4}$ & 0.00020 & 0.046 & Low & 1 \\
\hline $\begin{array}{c}\text { Male } \\
\text { Professional } \\
\text { Alpine } \\
\text { Skiing }\end{array}$ & $\mathbf{0 . 0 0 7 1}$ & 0.0038 & 0.013 & Low & 10 \\
\hline $\begin{array}{c}\text { Male High } \\
\text { School } \\
\text { Football }\end{array}$ & $\mathbf{0 . 0 0 6 8}$ & 0.0033 & 0.014 & Low & 113 \\
\hline $\begin{array}{c}\text { Female } \\
\text { Professional } \\
\text { Volleyball }\end{array}$ & $\mathbf{0 . 0 0 6 2 9}$ & 0.0030 & 0.013 & Low & 10 \\
\hline $\begin{array}{c}\text { Female } \\
\text { Collegiate } \\
\text { Rugby }\end{array}$ & $\mathbf{0 . 0 0 8 8 4}$ & 0.0034 & 0.023 & Low & 7 \\
\hline $\begin{array}{c}\text { Female } \\
\text { Collegiate } \\
\text { Soccer }\end{array}$ & $\mathbf{0 . 0 0 6 1 1}$ & 0.0022 & 0.017 & Low & 169 \\
\hline $\begin{array}{c}\text { Female } \\
\text { High School } \\
\text { Lacrosse }\end{array}$ & $\mathbf{0 . 0 0 5 6 1}$ & 0.0013 & 0.024 & Low & 5 \\
\hline $\begin{array}{c}\text { Male } \\
\text { Professional } \\
\text { Basketball }\end{array}$ & $\mathbf{0 . 0 0 5 1 3}$ & 0.0021 & 0.012 & Low & \\
\hline
\end{tabular}




\begin{tabular}{|c|c|c|c|c|c|}
\hline $\begin{array}{c}\text { Female } \\
\text { High School } \\
\text { Soccer }\end{array}$ & 0.00476 & 0.0021 & 0.011 & Low & 149 \\
\hline $\begin{array}{c}\text { Male } \\
\text { Professional } \\
\text { Soccer }\end{array}$ & 0.0044 & 0.0016 & 0.012 & Low & 433 \\
\hline $\begin{array}{c}\text { Female } \\
\text { Collegiate } \\
\text { Basketball }\end{array}$ & 0.00428 & 0.0023 & 0.0079 & Low & 196 \\
\hline $\begin{array}{l}\text { Male High } \\
\text { School } \\
\text { Lacrosse }\end{array}$ & 0.00406 & 0.0013 & 0.013 & Low & 6 \\
\hline $\begin{array}{c}\text { Male } \\
\text { Collegiate } \\
\text { Soccer }\end{array}$ & 0.00406 & 0.0019 & 0.0086 & Low & 117 \\
\hline $\begin{array}{l}\text { Male High } \\
\text { School } \\
\text { Rugby }\end{array}$ & 0.00346 & 0.00010 & 0.019 & Low & 1 \\
\hline $\begin{array}{c}\text { Male } \\
\text { Professional } \\
\text { Ice Hockey }\end{array}$ & 0.00336 & 0.0014 & 0.0069 & Low & 7 \\
\hline $\begin{array}{c}\text { Female } \\
\text { High School } \\
\text { Volleyball }\end{array}$ & 0.00293 & 0.0012 & 0.0074 & Low & 4 \\
\hline $\begin{array}{l}\text { Male High } \\
\text { School } \\
\text { Basketball }\end{array}$ & 0.0025 & 0.0013 & 0.0047 & Low & 12 \\
\hline $\begin{array}{c}\text { Male } \\
\text { Collegiate } \\
\text { Football }\end{array}$ & 0.0024 & 0.00017 & 0.033 & Low & 82 \\
\hline $\begin{array}{c}\text { Female } \\
\text { High School } \\
\text { Field } \\
\text { Hockey }\end{array}$ & 0.0023 & 0.000058 & 0.013 & Low & 1 \\
\hline $\begin{array}{c}\text { Male } \\
\text { Collegiate } \\
\text { Basketball }\end{array}$ & 0.0016 & 0.00064 & 0.0040 & Low & 58 \\
\hline $\begin{array}{c}\text { Female } \\
\text { Professional } \\
\text { Netball }\end{array}$ & 0.0014 & 0.00044 & 0.092 & Low & 1 \\
\hline $\begin{array}{l}\text { Male High } \\
\text { School } \\
\text { Wrestling }\end{array}$ & 0.0014 & 0.00046 & 0.0033 & Low & 5 \\
\hline
\end{tabular}




\begin{tabular}{|c|c|c|c|c|c|}
\hline $\begin{array}{c}\text { Male } \\
\text { Collegiate } \\
\text { Ice Hockey }\end{array}$ & $\mathbf{0 . 0 0 1 4}$ & 0.00046 & 0.0044 & Low & 3 \\
\hline $\begin{array}{c}\text { Male High } \\
\text { School } \\
\text { Soccer }\end{array}$ & $\mathbf{0 . 0 0 1 3}$ & 0.00041 & 0.0042 & Low & 299 \\
\hline $\begin{array}{c}\text { Female } \\
\text { Collegiate } \\
\text { Ice Hockey }\end{array}$ & $\mathbf{0 . 0 0 0 9 8}$ & 0.00014 & 0.0069 & Low & 1 \\
\hline $\begin{array}{c}\text { Female } \\
\text { Collegiate } \\
\text { Lacrosse }\end{array}$ & $\mathbf{0 . 0 0 0 7 8}$ & 0.00026 & 0.0023 & Low & 14 \\
\hline $\begin{array}{c}\text { Male } \\
\text { Collegiate } \\
\text { Lacrosse }\end{array}$ & $\mathbf{0 . 0 0 0 6 6}$ & 0.00035 & 0.0013 & Low & 15 \\
\hline
\end{tabular}

Table 1: Combined injury rate of anterior cruciate ligament injuries and their associated level of risk 


\section{Discussion}

The purpose of our study was to characterize ACL injury risk across various sports/sex/and levels, as the first step towards creating a risk assessment tool. Throughout the systematic review and meta-analysis, there were many obstacles and gaps within the data of this subject.

It is first worth noting that most of the studies we looked at were of high or moderate quality $(84 \%)$ while only $(16 \%)$ were of lower quality. Therefore, the majority of the articles were of low bias and can therefore be considered robust indicators for prevalence estimation.

As seen in Table 1 the highest risk sports were Female High School Floorball (incidence rate $=0.042[0.0087,0.12]$ ), Female High School Handball (incidence rate $=0.04[0.011,0.099])$, Female Collegiate Handball (incidence rate $=0.037[0.012$, 0.083]), Male Professional Football (incidence rate $=0.030[0.028,0.032]$ ), Female Professional Basketball (incidence rate $=0.027[0.0075,0.096]$ ), Female Youth Soccer (incidence rate $=0.022[0.018,0.028])$, Female Professional Handball (incidence rate $=$ $0.022[0.013,0.036]$ ), and Male Professional Handball (incidence rate $=0.022[0.0060$, 0.055]). Out of the eight highest risk sports, 6 of them occurred in the female population. It is worth noting that only 4 of these sports had more than $10 \mathrm{ACL}$ injuries, so the estimates are likely to be imprecise compared to previous literature that found girls are 3

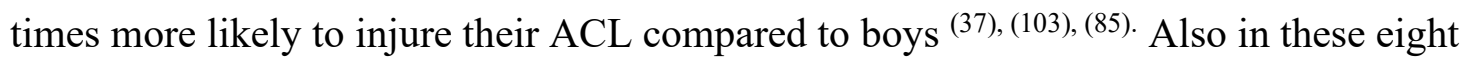
subgroupings, 4 of them occurred in the sport of handball. 
As mentioned in the methods section of this paper, there were various studies that included sports with 0 ACL injuries. Due to this, we could not use them in our analysis because it was not a reliable estimate. Therefore, more data is needed due to insufficient number of studies and low sample size of the event (i.e., ACL injuries). These studies included the sports of ballet, dance, field hockey, floorball, gymnastics, and volleyball. More research and future studies need to account and look at these subjects to get a more accurate estimation of risk in these sport populations. Common sports were identified through these studies such as basketball or soccer. These more popular sports usually gather information from a surveillance database. However, when looking at Figure 2 there is not a lot of data for some other sports like Baseball/Softball, Handball or Rugby. Even when conducting the literature search, there were no studies found that looked at various other sports such as tennis or snowboarding. Thus, future studies should focus on including more data for these underrepresented sports, in addition to collecting more surveillance data for these less common subgroups.

In previous literature it is seen that neuromuscular training is most effective at a younger age (14-18), ${ }^{(73),(93)}$ and in our study the injury rates were higher for the professional athletes. This is particularly interesting because professional sports have more access to resources and training programs compared to youth or high school level sports. Future research may investigate developing more effective prevention programs for professional athletes to decrease injury rates. 
To determine if an article had a sufficient sample size population, we went off the rule of greater than or equal to ten ACL injuries ${ }^{(23) .}$ There were fifty-three combined categories of sex, sport type and level. Out of these fifty-three subgroups, twenty-four of the subgroups had a sufficient sample size, while twenty-nine had an insufficient sample size. This shows that over half (54\%) had less than $10 \mathrm{ACL}$ injuries per subgroup, which again denotes the need for more studies to be conducted.

Although it might be easy to assume and point out that females are more at risk for ACL injury within sports, it cannot be proposed as a blanket statement. This research brings to light a very important fact. Risk is highly dependent on a multitude of things, in particular the type of sport that is played. People should be cautious when grouping or overgeneralization of sex specific injury risk because the type of sport and level also needs to be taken into consideration.

The beginning aim of this project was to create a personalized risk assessment tool for athletes to use to determine their risk of sustaining an ACL injury. However, as research was being conducted it was very apparent that much more research needs to be done within specific subgroups of the athlete population before a tool can be created. Without enough data and information, the injury rates are not reliable.

\subsubsection{Limitations}

Due to the nature of such a large meta-analysis, with about 80 studies included, there are obvious weaknesses and limitations to this research. First, due to a wide range of inclusion and exclusion criteria there were numerous articles to assess. Some were not 
accessible, and others found duplicates. As such, there is always a possibility of not capturing all necessary articles within our search criteria as well as data that is unpublished. Also, not all articles reported the rate of ACL injuries in the same format.

Calculations and other assumptions had to be made which could lead to bias. Many articles were reviewed to find specific inclusion and exclusion criteria, namely the total participants. Not all studies reported this information and thus we had to calculate total participants based upon the average roster size for a specific subgroup of a sport. As this number is not concrete, there can be some variation and bias.

\subsubsection{Future Goals}

Based upon our research and meta-analysis of numerous articles, a risk assessment tool would prove very useful. We were not able to develop the risk calculator itself, as it would need more data, testing, and validation. However, using the findings of this paper could support general risk assessment to increase motivation for prevention initiatives as well as filling gaps in prevalence data reporting.

\subsubsection{Conclusions}

There was substantial variability in injury rates within and across sports. In general, the highest injury rates occurred in professional sports, warranting the need for more prevention training initiatives. In a majority of the rates female athletes had a greater risk of ACL injury compared to male athletes. However, due to the gaps in data, this cannot be assumed or made to be true for every sport or level. Researchers and 
practitioners need to be cautious about overgeneralization of sex and sport differences in ACL injury risk. Future studies should aim at more complete coverage of sports at all levels of play, and sex to have more data as means of comparison. When more information is discovered, a personalized risk assessment tool can be developed to then determine the most at-risk population to allocate resources and prevention training to reduce the number of ACL injuries. 


\section{References}

1. Agel J, Arendt EA, Bershadsky B. Anterior cruciate ligament injury in national collegiate athletic association basketball and soccer: a 13-year review. Am J Sports Med. 2005;33(4):524-530.

2. Agel J, Rockwood T, Klossner D. Collegiate ACL Injury Rates Across 15 Sports: National Collegiate Athletic Association Injury Surveillance System Data Update (2004-2005 Through 2012-2013). Clin J Sport Med. 2016;26(6):518-523.

3. Ajuied A, Wong F, Smith C, et al. Anterior cruciate ligament injury and radiologic progression of knee osteoarthritis: a systematic review and metaanalysis. Am J Sports Med. 2014;42(9):2242-2252.

4. Anterior Cruciate Ligament (ACL) Injuries. OrthoInfo - AAOS. https://orthoinfo.aaos.org/en/diseases--conditions/anterior-cruciate-ligament-aclinjuries/. Published 2014. Accessed 06/30, 2021.

5. Ardern CL, Taylor NF, Feller JA, Webster KE. Fifty-five per cent return to competitive sport following anterior cruciate ligament reconstruction surgery: an updated systematic review and meta-analysis including aspects of physical functioning and contextual factors. Br J Sports Med. 2014;48(21):1543-1552.

6. Ardern CL, Webster KE, Taylor NF, Feller JA. Return to the preinjury level of competitive sport after anterior cruciate ligament reconstruction surgery: twothirds of patients have not returned by 12 months after surgery. Am J Sports Med. 2011;39(3):538-543.

7. Arendt EA, Agel J, Dick R. Anterior cruciate ligament injury patterns among collegiate men and women. J Athl Train. 1999;34(2):86-92.

8. Athlete Exposure Segen's Medical Dictionary https://medicaldictionary.thefreedictionary.com/Athlete+Exposure. Published 2011. Accessed 06/30, 2021.

9. Awwad GEH, Coleman JH, Dunkley CJ, Dewar DC. An Analysis of Knee Injuries in Rugby League: The Experience at the Newcastle Knights Professional Rugby League Team. Sports Med Open. 2019;5(1):33.

10. Balduzzi S, Rücker G, Schwarzer G (2019). "How to perform a meta-analysis with R: a practical tutorial.” Evidence-Based Mental Health, 153-160.

11. Barenius B, Ponzer S, Shalabi A, Bujak R, Norlen L, Eriksson K. Increased risk of osteoarthritis after anterior cruciate ligament reconstruction: a 14-year followup study of a randomized controlled trial. Am J Sports Med. 2014;42(5):10491057. 
12. Beynnon BD, Vacek PM, Newell MK, et al. The Effects of Level of Competition, Sport, and Sex on the Incidence of First-Time Noncontact Anterior Cruciate Ligament Injury. Am J Sports Med. 2014;42(8):1806-1812.

13. Bjorneboe J, Bahr R, Andersen TE. Risk of injury on third-generation artificial turf in Norwegian professional football. Br J Sports Med. 2010;44(11):794-798.

14. Bonato M, Benis R, La Torre A. Neuromuscular training reduces lower limb injuries in elite female basketball players. A cluster randomized controlled trial. Scand J Med Sci Sports. 2018;28(4):1451-1460.

15. Bradley JP, Klimkiewicz JJ, Rytel MJ, Powell JW. Anterior cruciate ligament injuries in the National Football League: epidemiology and current treatment trends among team physicians. Arthroscopy. 2002;18(5):502-509.

16. Brooks JH, Fuller CW, Kemp SP, Reddin DB. Epidemiology of injuries in English professional rugby union: part 1 match injuries. Br J Sports Med. 2005;39(10):757-766.

17. Brooks JH, Fuller CW, Kemp SP, Reddin DB. Epidemiology of injuries in English professional rugby union: part 2 training Injuries. Br J Sports Med. 2005;39(10):767-775.

18. Caine DJ, Golightly YM. Osteoarthritis as an outcome of paediatric sport: an epidemiological perspective. Br J Sports Med. 2011;45(4):298-303.

19. Caraffa A, Cerulli G, Projetti M, Aisa G, Rizzo A. Prevention of anterior cruciate ligament injuries in soccer. A prospective controlled study of proprioceptive training. Knee Surg Sports Traumatol Arthrosc. 1996;4(1):19-21.

20. Cinque ME, Dornan GJ, Chahla J, Moatshe G, LaPrade RF. High Rates of Osteoarthritis Develop After Anterior Cruciate Ligament Surgery: An Analysis of 4108 Patients. Am J Sports Med. 2018;46(8):2011-2019.

21. Dallalana RJ, Brooks JH, Kemp SP, Williams AM. The epidemiology of knee injuries in English professional rugby union. Am J Sports Med. 2007;35(5):818830.

22. Darrow CJ, Collins CL, Yard EE, Comstock RD. Epidemiology of severe injuries among United States high school athletes: 2005-2007. Am J Sports Med. 2009;37(9):1798-1805.

23. Deeks JJ, Higgins JPT, Altman DG (editors). Chapter 10: Analysing data and undertaking meta-analyses. In: Higgins JPT, Thomas J, Chandler J, Cumpston M, Li T, Page MJ, Welch VA (editors). Cochrane Handbook for Systematic Reviews of Interventions version 6.2 (updated February 2021). Cochrane, 2021. Available from www.training.cochrane.org/handbook.

24. Deitch JR, Starkey C, Walters SL, Moseley JB. Injury risk in professional basketball players: a comparison of Women's National Basketball Association and 
National Basketball Association athletes. Am J Sports Med. 2006;34(7):10771083.

25. DeLee JC, Farney WC. Incidence of injury in Texas high school football. Am J Sports Med. 1992;20(5):575-580.

26. Devetag F, Mazzilli M, Benis R, A LAT, Bonato M. Anterior cruciate ligament injury profile in Italian Serie A1-A2 women's volleyball league. J Sports Med Phys Fitness. 2018;58(1-2):92-97.

27. Dodson CC, Secrist ES, Bhat SB, Woods DP, Deluca PF. Anterior Cruciate Ligament Injuries in National Football League Athletes From 2010 to 2013: A Descriptive Epidemiology Study. Orthop J Sports Med. 2016;4(3):2325967116631949.

28. Donmez G, Korkusuz F, Ozcakar L, et al. Injuries Among Recreational Football Players: Results of a Prospective Cohort Study. Clin J Sport Med. 2018;28(3):249-254.

29. Dragoo JL, Braun HJ, Durham JL, Chen MR, Harris AH. Incidence and risk factors for injuries to the anterior cruciate ligament in National Collegiate Athletic Association football: data from the 2004-2005 through 2008-2009 National Collegiate Athletic Association Injury Surveillance System. Am J Sports Med. 2012;40(5):990-995.

30. Faude O, Junge A, Kindermann W, Dvorak J. Injuries in female soccer players: a prospective study in the German national league. Am J Sports Med. 2005;33(11):1694-1700.

31. Faude O, Junge A, Kindermann W, Dvorak J. Risk factors for injuries in elite female soccer players. Br J Sports Med. 2006;40(9):785-790.

32. Filbay SR, Culvenor AG, Ackerman IN, Russell TG, Crossley KM. Quality of life in anterior cruciate ligament-deficient individuals: a systematic review and metaanalysis. Br J Sports Med. 2015;49(16):1033-1041.

33. Gage BE, McIlvain NM, Collins CL, Fields SK, Comstock RD. Epidemiology of 6.6 million knee injuries presenting to United States emergency departments from 1999 through 2008. Acad Emerg Med. 2012;19(4):378-385.

34. Gilchrist J, Mandelbaum BR, Melancon H, et al. A randomized controlled trial to prevent noncontact anterior cruciate ligament injury in female collegiate soccer players. Am J Sports Med. 2008;36(8):1476-1483.

35. Giza E, Mithofer K, Farrell L, Zarins B, Gill T. Injuries in women's professional soccer. Br J Sports Med. 2005;39(4):212-216; discussion 212-216.

36. Gomez E, DeLee JC, Farney WC. Incidence of injury in Texas girls' high school basketball. Am J Sports Med. 1996;24(5):684-687. 
37. Gornitzky AL, Lott A, Yellin JL, Fabricant PD, Lawrence JT, Ganley TJ. SportSpecific Yearly Risk and Incidence of Anterior Cruciate Ligament Tears in High School Athletes: A Systematic Review and Meta-analysis. Am J Sports Med. 2016;44(10):2716-2723.

38. Grassi A, Macchiarola L, Filippini M, Lucidi GA, Della Villa F, Zaffagnini S. Epidemiology of Anterior Cruciate Ligament Injury in Italian First Division Soccer Players. Sports Health. 2020;12(3):279-288.

39. Gupta AS, Pierpoint LA, Comstock RD, Saper MG. Sex-Based Differences in Anterior Cruciate Ligament Injuries Among United States High School Soccer Players: An Epidemiological Study. Orthop J Sports Med. 2020;8(5):2325967120919178.

40. Hagglund M, Atroshi I, Wagner P, Walden M. Superior compliance with a neuromuscular training programme is associated with fewer ACL injuries and fewer acute knee injuries in female adolescent football players: secondary analysis of an RCT. Br J Sports Med. 2013;47(15):974-979.

41. Hagglund M, Walden M, Ekstrand J. Injuries among male and female elite football players. Scand J Med Sci Sports. 2009;19(6):819-827.

42. Haida A, Coulmy N, Dor F, et al. Return to Sport Among French Alpine Skiers After an Anterior Cruciate Ligament Rupture: Results From 1980 to 2013. Am J Sports Med. 2016;44(2):324-330.

43. Harmon KG, Dick R. The relationship of skill level to anterior cruciate ligament injury. Clin J Sport Med. 1998;8(4):260-265.

44. Heidt RS, Jr., Sweeterman LM, Carlonas RL, Traub JA, Tekulve FX. Avoidance of soccer injuries with preseason conditioning. Am J Sports Med. 2000;28(5):659662.

45. Herzog MM, Marshall SW, Lund JL, Pate V, Mack CD, Spang JT. Incidence of Anterior Cruciate Ligament Reconstruction Among Adolescent Females in the United States, 2002 Through 2014. JAMA Pediatr. 2017;171(8):808-810.

46. Hewett TE, Lindenfeld TN, Riccobene JV, Noyes FR. The effect of neuromuscular training on the incidence of knee injury in female athletes. A prospective study. Am J Sports Med. 1999;27(6):699-706.

47. Howard JS, Lembach ML, Metzler AV, Johnson DL. Rates and Determinants of Return to Play After Anterior Cruciate Ligament Reconstruction in National Collegiate Athletic Association Division I Soccer Athletes: A Study of the Southeastern Conference. Am J Sports Med. 2016;44(2):433-439.

48. Inclan PM, Chang PS, Mack CD, et al. Validity of Research Based on Public Data in Sports Medicine: A Quantitative Assessment of Anterior Cruciate Ligament 
Injuries in the National Football League. Am J Sports Med.

2021:3635465211015435.

49. Joseph AM, Collins CL, Henke NM, Yard EE, Fields SK, Comstock RD. A multisport epidemiologic comparison of anterior cruciate ligament injuries in high school athletics. J Athl Train. 2013;48(6):810-817.

50. Kelley B, Carchia C. "Hey, data data -- swing!". ESPN Internet Ventures https://www.espn.com/espn/story/_id/9469252/hidden-demographics-youthsports-espn-magazine. Published 2013. Accessed 06/30, 2021.

51. Kester BS, Behery OA, Minhas SV, Hsu WK. Athletic performance and career longevity following anterior cruciate ligament reconstruction in the National Basketball Association. Knee Surg Sports Traumatol Arthrosc. 2017;25(10):30313037.

52. LaBella CR, Huxford MR, Grissom J, Kim KY, Peng J, Christoffel KK. Effect of neuromuscular warm-up on injuries in female soccer and basketball athletes in urban public high schools: cluster randomized controlled trial. Arch Pediatr Adolesc Med. 2011;165(11):1033-1040.

53. Lambson RB, Barnhill BS, Higgins RW. Football cleat design and its effect on anterior cruciate ligament injuries. A three-year prospective study. Am J Sports Med. 1996;24(2):155-159.

54. LaPrade RF, Burnett QM, 2nd. Femoral intercondylar notch stenosis and correlation to anterior cruciate ligament injuries. A prospective study. Am J Sports Med. 1994;22(2):198-202; discussion 203.

55. Larruskain J, Lekue JA, Diaz N, Odriozola A, Gil SM. A comparison of injuries in elite male and female football players: A five-season prospective study. Scand J Med Sci Sports. 2018;28(1):237-245.

56. Le Gall F, Carling C, Reilly T. Injuries in young elite female soccer players: an 8season prospective study. Am J Sports Med. 2008;36(2):276-284.

57. Levy AS, Wetzler MJ, Lewars M, Laughlin W. Knee injuries in women collegiate rugby players. Am J Sports Med. 1997;25(3):360-362.

58. Liederbach M, Dilgen FE, Rose DJ. Incidence of anterior cruciate ligament injuries among elite ballet and modern dancers: a 5-year prospective study. Am J Sports Med. 2008;36(9):1779-1788.

59. Lombardo S, Sethi PM, Starkey C. Intercondylar notch stenosis is not a risk factor for anterior cruciate ligament tears in professional male basketball players: an 11year prospective study. Am J Sports Med. 2005;33(1):29-34.

60. Longstaffe R, Leiter J, MacDonald P. Anterior Cruciate Ligament Injuries in the National Hockey League: Epidemiology and Performance Impact. Clin J Sport Med. 2020;30(3):224-230. 
61. Mai HT, Alvarez AP, Freshman RD, et al. The NFL Orthopaedic Surgery Outcomes Database (NO-SOD): The Effect of Common Orthopaedic Procedures on Football Careers. Am J Sports Med. 2016;44(9):2255-2262.

62. Mandelbaum BR, Silvers HJ, Watanabe DS, et al. Effectiveness of a neuromuscular and proprioceptive training program in preventing anterior cruciate ligament injuries in female athletes: 2-year follow-up. Am J Sports Med. 2005;33(7):1003-1010.

63. Mather RC, 3rd, Koenig L, Kocher MS, et al. Societal and economic impact of anterior cruciate ligament tears. J Bone Joint Surg Am. 2013;95(19):1751-1759.

64. Messina DF, Farney WC, DeLee JC. The incidence of injury in Texas high school basketball. A prospective study among male and female athletes. Am J Sports Med. 1999;27(3):294-299.

65. Meta-analysis Wikimedia Foundation https://en.wikipedia.org/wiki/Metaanalysis. Published 2021. Accessed 06/30, 2021.

66. Meyers MC, Barnhill BS. Incidence, causes, and severity of high school football injuries on FieldTurf versus natural grass: a 5-year prospective study. Am J Sports Med. 2004;32(7):1626-1638.

67. Meyers MC. Incidence, mechanisms, and severity of game-related college football injuries on FieldTurf versus natural grass: a 3-year prospective study. Am J Sports Med. 2010;38(4):687-697.

68. Meyers MC. Incidence, mechanisms, and severity of match-related collegiate women's soccer injuries on FieldTurf and natural grass surfaces: a 5-year prospective study. Am J Sports Med. 2013;41(10):2409-2420.

69. Mihata LC, Beutler AI, Boden BP. Comparing the incidence of anterior cruciate ligament injury in collegiate lacrosse, soccer, and basketball players: implications for anterior cruciate ligament mechanism and prevention. Am J Sports Med. 2006;34(6):899-904.

70. Montalvo AM, Schneider DK, Silva PL, et al. 'What's my risk of sustaining an ACL injury while playing football (soccer)?' A systematic review with metaanalysis. Br J Sports Med. 2019;53(21):1333-1340.

71. Montalvo AM, Schneider DK, Webster KE, et al. Anterior Cruciate Ligament Injury Risk in Sport: A Systematic Review and Meta-Analysis of Injury Incidence by Sex and Sport Classification. J Athl Train. 2019;54(5):472-482.

72. Munn Z, Moola S, Lisy K, Riitano D, Tufanaru C. Methodological guidance for systematic reviews of observational epidemiological studies reporting prevalence and cumulative incidence data. Int J Evid Based Healthc. 2015;13(3):147-153.

73. Myer GD, Sugimoto D, Thomas S, Hewett TE. The Influence of Age on the Effectiveness of Neuromuscular Training to Reduce Anterior Cruciate Ligament 
Injury in Female Athletes A Meta-Analysis. Am J Sports Med 2013;41:203-15.

https://doi.org/10.1177/0363546512460637. PMID: 23048042, PMCID:

PMC4160039

74. Myklebust G, Engebretsen L, Braekken IH, Skjolberg A, Olsen OE, Bahr R.

Prevention of anterior cruciate ligament injuries in female team handball players: a prospective intervention study over three seasons. Clin J Sport Med. 2003; 13(2):71-78.

75. Nilstad A, Andersen TE, Bahr R, Holme I, Steffen K. Risk factors for lower extremity injuries in elite female soccer players. Am J Sports Med. 2014;42(4):940-948.

76. Oiestad BE, Engebretsen L, Storheim K, Risberg MA. Knee osteoarthritis after anterior cruciate ligament injury: a systematic review. Am J Sports Med. 2009;37(7):1434-1443.

77. Omi Y, Sugimoto D, Kuriyama S, et al. Effect of Hip-Focused Injury Prevention Training for Anterior Cruciate Ligament Injury Reduction in Female Basketball Players: A 12-Year Prospective Intervention Study. Am J Sports Med. 2018;46(4):852-861.

78. Oshima T, Nakase J, Kitaoka K, et al. Poor static balance is a risk factor for noncontact anterior cruciate ligament injury. Arch Orthop Trauma Surg. 2018;138(12):1713-1718.

79. Ostenberg A, Roos H. Injury risk factors in female European football. A prospective study of 123 players during one season. Scand J Med Sci Sports. 2000;10(5):279-285.

80. Padua DA, DiStefano LJ, Beutler AI, de la Motte SJ, DiStefano MJ, Marshall SW. The Landing Error Scoring System as a Screening Tool for an Anterior Cruciate Ligament Injury-Prevention Program in Elite-Youth Soccer Athletes. J Athl Train. 2015;50(6):589-595.

81. Page MJ, McKenzie JE, Bossuyt PM, et al. The PRISMA 2020 statement: an updated guideline for reporting systematic reviews. Syst Rev. 2021;10(1):89.

82. Pasanen K, Hietamo J, Vasankari T, et al. Acute injuries in Finnish junior floorball league players. J Sci Med Sport. 2018;21(3):268-273.

83. Pasanen K, Parkkari J, Pasanen M, et al. Neuromuscular training and the risk of leg injuries in female floorball players: cluster randomised controlled study. BMJ. 2008;337:a295.

84. Petersen W, Braun C, Bock W, et al. A controlled prospective case control study of a prevention training program in female team handball players: the German experience. Arch Orthop Trauma Surg. 2005;125(9):614-621. 
85. Prodromos CC, Han Y, Rogowski J, Joyce B, Shi K. A meta-analysis of the incidence of anterior cruciate ligament tears as a function of gender, sport, and a knee injury-reduction regimen. Arthroscopy. 2007;23(12):1320-1325 e1326.

86. Pujol N, Blanchi MP, Chambat P. The incidence of anterior cruciate ligament injuries among competitive Alpine skiers: a 25-year investigation. Am J Sports Med. 2007;35(7):1070-1074.

87. Quisquater L, Bollars P, Vanlommel L, Claes S, Corten K, Bellemans J. The incidence of knee and anterior cruciate ligament injuries over one decade in the Belgian Soccer League. Acta Orthop Belg. 2013;79(5):541-546.

88. Raschner C, Platzer HP, Patterson C, Werner I, Huber R, Hildebrandt C. The relationship between ACL injuries and physical fitness in young competitive ski racers: a 10-year longitudinal study. Br J Sports Med. 2012;46(15):1065-1071.

89. Rekik RN, Tabben M, Eirale C, et al. ACL injury incidence, severity and patterns in professional male soccer players in a Middle Eastern league. BMJ Open Sport Exerc Med. 2018;4(1):e000461.

90. Rochcongar P, Laboute E, Jan J, Carling C. Ruptures of the anterior cruciate ligament in soccer. Int J Sports Med. 2009;30(5):372-378.

91. Roi GSN, G.; Tavana, R.; Tencone, F. Prevalence of anterior cruciate ligament reconstructions in professional soccer players Sport sciences for health. 2006;1(3):118-121.

92. Roos H, Ornell M, Gardsell P, Lohmander LS, Lindstrand A. Soccer after anterior cruciate ligament injury--an incompatible combination? A national survey of incidence and risk factors and a 7-year follow-up of 310 players. Acta Orthop Scand. 1995;66(2):107-112.

93. Sanders TL, Kremers HM, Bryan AJ, Larson DR, Dahm DL, Levy BA, et al. Incidence of Anterior Cruciate Ligament Tears and Reconstruction A 21-Year Population-Based Study. Am J Sports Med 2016;44:1502-7. https://doi.org/10.1177/0363546516629944. PMID: 26920430

94. Schiffner E, Latz D, Grassmann JP, et al. Anterior cruciate ligament ruptures in German elite soccer players: Epidemiology, mechanisms, and return to play. Knee. 2018;25(2):219-225.

95. Scranton PE, Jr., Whitesel JP, Powell JW, et al. A review of selected noncontact anterior cruciate ligament injuries in the National Football League. Foot Ankle Int. 1997;18(12):772-776.

96. Seil R, Rupp S, Tempelhof S, Kohn D. Sports injuries in team handball. A oneyear prospective study of sixteen men's senior teams of a superior nonprofessional level. Am J Sports Med. 1998;26(5):681-687. 
97. Shea KG, Pfeiffer R, Wang JH, Curtin M, Apel PJ. Anterior cruciate ligament injury in pediatric and adolescent soccer players: an analysis of insurance data. $\mathrm{J}$ Pediatr Orthop. 2004;24(6):623-628.

98. Silvers-Granelli HJ, Bizzini M, Arundale A, Mandelbaum BR, Snyder-Mackler L. Does the FIFA 11+ Injury Prevention Program Reduce the Incidence of ACL Injury in Male Soccer Players? Clin Orthop Relat Res. 2017;475(10):2447-2455.

99. Singh P, Mansingh A, Palmer W, Williams EW. Injuries in elite Jamaican netballers. West Indian Med J. 2013;62(2):118-121.

100. Soderman K, Alfredson H, Pietila T, Werner S. Risk factors for leg injuries in female soccer players: a prospective investigation during one out-door season. Knee Surg Sports Traumatol Arthrosc. 2001;9(5):313-321.

101. Soderman K, Werner S, Pietila T, Engstrom B, Alfredson H. Balance board training: prevention of traumatic injuries of the lower extremities in female soccer players? A prospective randomized intervention study. Knee Surg Sports Traumatol Arthrosc. 2000;8(6):356-363.

102. Soomro N, Sanders R, Hackett D, et al. The Efficacy of Injury Prevention Programs in Adolescent Team Sports: A Meta-analysis. Am J Sports Med. 2016;44(9):2415-2424.

103. Stanley LE, Kerr ZY, Dompier TP, Padua DA. Sex Differences in the Incidence of Anterior Cruciate Ligament, Medial Collateral Ligament, and Meniscal Injuries in Collegiate and High School Sports: 2009-2010 Through 2013-2014. Am J Sports Med. 2016;44(6):1565-1572.

104. Steffen K, Myklebust G, Olsen OE, Holme I, Bahr R. Preventing injuries in female youth football--a cluster-randomized controlled trial. Scand J Med Sci Sports. 2008;18(5):605-614.

105. Steffen K, Nilstad A, Kristianslund EK, Myklebust G, Bahr R, Krosshaug T. Association between Lower Extremity Muscle Strength and Noncontact ACL Injuries. Med Sci Sports Exerc. 2016;48(11):2082-2089.

106. Sugimoto D, Myer GD, Barber Foss KD, Pepin MJ, Micheli LJ, Hewett TE. Critical components of neuromuscular training to reduce ACL injury risk in female athletes: meta-regression analysis. Br J Sports Med. 2016;50(20):12591266.

107. Sugimoto D, Myer GD, Foss KD, Hewett TE. Specific exercise effects of preventive neuromuscular training intervention on anterior cruciate ligament injury risk reduction in young females: meta-analysis and subgroup analysis. Br J Sports Med. 2015;49(5):282-289.

108. Suter LG, Smith SR, Katz JN, et al. Projecting Lifetime Risk of Symptomatic Knee Osteoarthritis and Total Knee Replacement in Individuals Sustaining a 
Complete Anterior Cruciate Ligament Tear in Early Adulthood. Arthritis Care Res (Hoboken). 2017;69(2):201-208.

109. Takazawa $Y$, Nagayama M, Ikeda $\mathrm{H}$, et al. Anterior cruciate ligament injuries in elite and high school rugby players: a 11-year review. Phys Sportsmed. 2016;44(1):53-58.

110. Tegnander A, Olsen OE, Moholdt TT, Engebretsen L, Bahr R. Injuries in Norwegian female elite soccer: a prospective one-season cohort study. Knee Surg Sports Traumatol Arthrosc. 2008;16(2):194-198.

111. Tirabassi J, Brou L, Khodaee M, Lefort R, Fields SK, Comstock RD. Epidemiology of High School Sports-Related Injuries Resulting in Medical Disqualification: 2005-2006 Through 2013-2014 Academic Years. Am J Sports Med. 2016;44(11):2925-2932.

112. Trojian TH, Collins S. The anterior cruciate ligament tear rate varies by race in professional Women's basketball. Am J Sports Med. 2006;34(6):895-898.

113. Vauhnik R, Morrissey MC, Rutherford OM, Turk Z, Pilih IA, Perme MP. Rate and risk of anterior cruciate ligament injury among sportswomen in Slovenia. J Athl Train. 2011;46(1):92-98.

114. Viechtbauer W (2010). "Conducting meta-analyses in R with the metafor package." Journal of Statistical Software, 36(3), 1-48. https://doi.org/10.18637/jss.v036.i03.

115. Viola RW, Steadman JR, Mair SD, Briggs KK, Sterett WI. Anterior cruciate ligament injury incidence among male and female professional alpine skiers. Am J Sports Med. 1999;27(6):792-795.

116. Walden M, Atroshi I, Magnusson H, Wagner P, Hagglund M. Prevention of acute knee injuries in adolescent female football players: cluster randomised controlled trial. BMJ. 2012;344:e3042.

117. Walden M, Hagglund M, Magnusson H, Ekstrand J. Anterior cruciate ligament injury in elite football: a prospective three-cohort study. Knee Surg Sports Traumatol Arthrosc. 2011;19(1):11-19.

118. Wedderkopp N, Kaltoft M, Lundgaard B, Rosendahl M, Froberg K. Injuries in young female players in European team handball. Scand J Med Sci Sports. 1997;7(6):342-347.

119. Westin M, Harringe ML, Engstrom B, Alricsson M, Werner S. Prevention of Anterior Cruciate Ligament Injuries in Competitive Adolescent Alpine Skiers. Front Sports Act Living. 2020;2:11.

120. Westin M, Harringe ML, Engstrom B, Alricsson M, Werner S. Risk Factors for Anterior Cruciate Ligament Injury in Competitive Adolescent Alpine Skiers. Orthop J Sports Med. 2018;6(4):2325967118766830. 
121. Yale Medicine. (2021, May 13). Acl injury and treatments. Yale Medicine. https://www.yalemedicine.org/conditions/acl-injury-treatments.

122. Petushek EJ, Sugimoto D, Stoolmiller M, Smith G, Myer GD. Evidence-Based Best-Practice Guidelines for Preventing Anterior Cruciate Ligament Injuries in Young Female Athletes: A Systematic Review and Meta-analysis. Am J Sports Med. 2019 Jun;47(7):1744-1753. doi: 10.1177/0363546518782460. Epub 2018 Jul 12. PMID: 30001501; PMCID: PMC6592422. 


\section{A Appendix}

\section{A.1 Table of Data Extracted for all Studies Based on Sport Type, Level and Sex}

\begin{tabular}{|c|c|c|c|c|c|c|c|c|}
\hline $\begin{array}{l}\text { Sport } \\
\text { Type }\end{array}$ & Level & Author (s) \& Year & $\begin{array}{c}\text { Number } \\
\text { of ACLs } \\
\text { Injured } \\
\text { Per } \\
\text { Season }\end{array}$ & 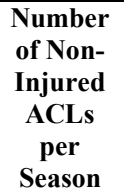 & $\begin{array}{c}\text { Injury } \\
\text { Rate }\end{array}$ & $\begin{array}{c}95 \% \\
\text { Confidence } \\
\text { Interval } \\
\text { (LBound) }\end{array}$ & $\begin{array}{c}95 \% \\
\text { Confidence } \\
\text { Interval } \\
\text { (UBound) }\end{array}$ & $\begin{array}{c}\text { Risk } \\
\text { of } \\
\text { Bias }\end{array}$ \\
\hline
\end{tabular}

\begin{tabular}{|c|c|c|c|c|c|c|c|c|}
\hline \multirow{14}{*}{ 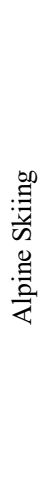 } & \multirow{8}{*}{$\begin{array}{l}\overrightarrow{0} \\
\dot{0} \\
\tilde{D} \\
\tilde{D} \\
\overrightarrow{0} \\
\overrightarrow{0}\end{array}$} & \multicolumn{7}{|c|}{ Female } \\
\hline & & Westin et. al $2020^{(119)}$ & 1 & 143 & 0.0070 & 0.00020 & 0.038 & 9 \\
\hline & & Westin et. al $2018^{(120)}$ & 4 & 160 & 0.025 & 0.0069 & 0.063 & 9 \\
\hline & & Combined Rate & 5 & 303 & 0.018 & 0.0058 & 0.053 & \\
\hline & & \multicolumn{7}{|c|}{ Male } \\
\hline & & Westin et. al $2020^{(119)}$ & 2 & 209 & 0.0096 & 0.0012 & 0.034 & 9 \\
\hline & & Westin et. al $2018^{(120)}$ & 3 & 173 & 0.017 & 0.0036 & 0.050 & 9 \\
\hline & & Combined Rate & 5 & 382 & 0.014 & 0.0057 & 0.032 & \\
\hline & \multirow{6}{*}{ 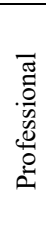 } & \multicolumn{7}{|c|}{ Female } \\
\hline & & Haida et. al $2016^{(42)}$ & 2 & 236 & 0.0085 & 0.0010 & 0.030 & 7 \\
\hline & & Pujol et. al $2007^{(86)}$ & 2 & 186 & 0.011 & 0.0013 & 0.038 & 8 \\
\hline & & 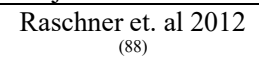 & 4 & 172 & 0.023 & 0.0064 & 0.059 & 8 \\
\hline & & Viola et. al $1999^{(115)}$ & 2 & 522 & 0.0038 & 0.00050 & 0.014 & 9 \\
\hline & & Combined Rate & $\mathbf{1 0}$ & 1116 & 0.010 & 0.0047 & 0.023 & \\
\hline
\end{tabular}

\begin{tabular}{|c|c|c|c|c|c|c|c|c|}
\hline \multirow{4}{*}{$\frac{\vec{\varrho}}{\bar{\varpi}}$} & \multirow{4}{*}{ 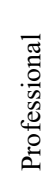 } & \multicolumn{7}{|c|}{ Female } \\
\hline & & 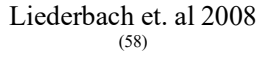 & 0 & 64 & 0 & 0 & 0.056 & 9 \\
\hline & & \multicolumn{7}{|c|}{ Male } \\
\hline & & 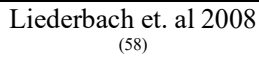 & 0 & 53 & 0 & 0 & 0.067 & 9 \\
\hline
\end{tabular}

\begin{tabular}{|c|c|c|c|c|c|c|c|c|}
\hline \multirow{16}{*}{ 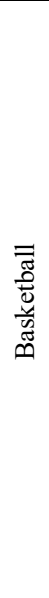 } & \multirow{16}{*}{$\begin{array}{l}\overrightarrow{8} \\
\overline{0} \\
\tilde{D} \\
\overrightarrow{0} \\
\overrightarrow{0} \\
\overrightarrow{0}\end{array}$} & \multicolumn{7}{|c|}{ Female } \\
\hline & & $\underset{(12)}{\text { Beynnon et. al } 2014}$ & 2 & 974 & 0.0021 & 0.00020 & 0.0074 & $\overline{9}$ \\
\hline & & Gomez et. al $1996^{(36)}$ & 11 & 879 & 0.013 & 0.0063 & 0.022 & 9 \\
\hline & & Hewett et. al $1999^{(46)}$ & 3 & 186 & 0.016 & 0.0033 & 0.046 & 8 \\
\hline & & Joseph et. al $2013^{(49)}$ & 18 & 1482 & 0.012 & 0.0072 & 0.019 & 8 \\
\hline & & Messina et. al $1999^{(64)}$ & 11 & 879 & 0.015 & 0.0063 & 0.022 & 9 \\
\hline & & Oshima et. al $2018^{(78)}$ & 5 & 167 & 0.030 & 0.0098 & 0.069 & 9 \\
\hline & & Stanley et. al $2016^{(103)}$ & 7 & 2138 & 0.0033 & 0.0016 & 0.0069 & 8 \\
\hline & & Combined Rate & 66 & 6936 & 0.012 & 0.0063 & 0.022 & \\
\hline & & \multicolumn{7}{|c|}{ Male } \\
\hline & & $\underset{(12)}{\text { Beynnon et. al }} 2014$ & 1 & 974 & 0.0010 & 0 & 0.0057 & 9 \\
\hline & & Hewett et. al $1999^{(46)}$ & 0 & 225 & 0 & 0 & 0.016 & 8 \\
\hline & & Joseph et. al $2013^{(49)}$ & 5 & 1495 & 0.0033 & 0.0011 & 0.0078 & 8 \\
\hline & & Messina et. al $1999^{(64)}$ & 4 & 969 & 0.0041 & 0.0011 & 0.011 & 9 \\
\hline & & Stanley et. al $2016^{(103)}$ & 2 & 2158 & 0.00093 & 0.00023 & 0.0037 & 8 \\
\hline & & Combined Rate & 12 & 5821 & 0.0025 & 0.0013 & 0.0047 & \\
\hline
\end{tabular}




\begin{tabular}{|c|c|c|c|c|c|c|c|c|}
\hline $\begin{array}{c}\text { Sport } \\
\text { Type }\end{array}$ & Level & Author (s) \& Year & $\begin{array}{c}\text { Number } \\
\text { of ACLs } \\
\text { Injured } \\
\text { Per } \\
\text { Season }\end{array}$ & $\begin{array}{c}\text { Number } \\
\text { of Non- } \\
\text { Injured } \\
\text { ACLs } \\
\text { per } \\
\text { Season }\end{array}$ & $\begin{array}{c}\text { Injury } \\
\text { Rate }\end{array}$ & $\begin{array}{c}\text { 95\% } \\
\text { Confidence } \\
\text { Interval } \\
\text { (LBound) }\end{array}$ & $\begin{array}{c}\text { 95\% } \\
\text { Confidence } \\
\text { Interval } \\
\text { (UBound) }\end{array}$ & $\begin{array}{c}\text { Risk } \\
\text { of } \\
\text { Bias }\end{array}$ \\
\hline
\end{tabular}

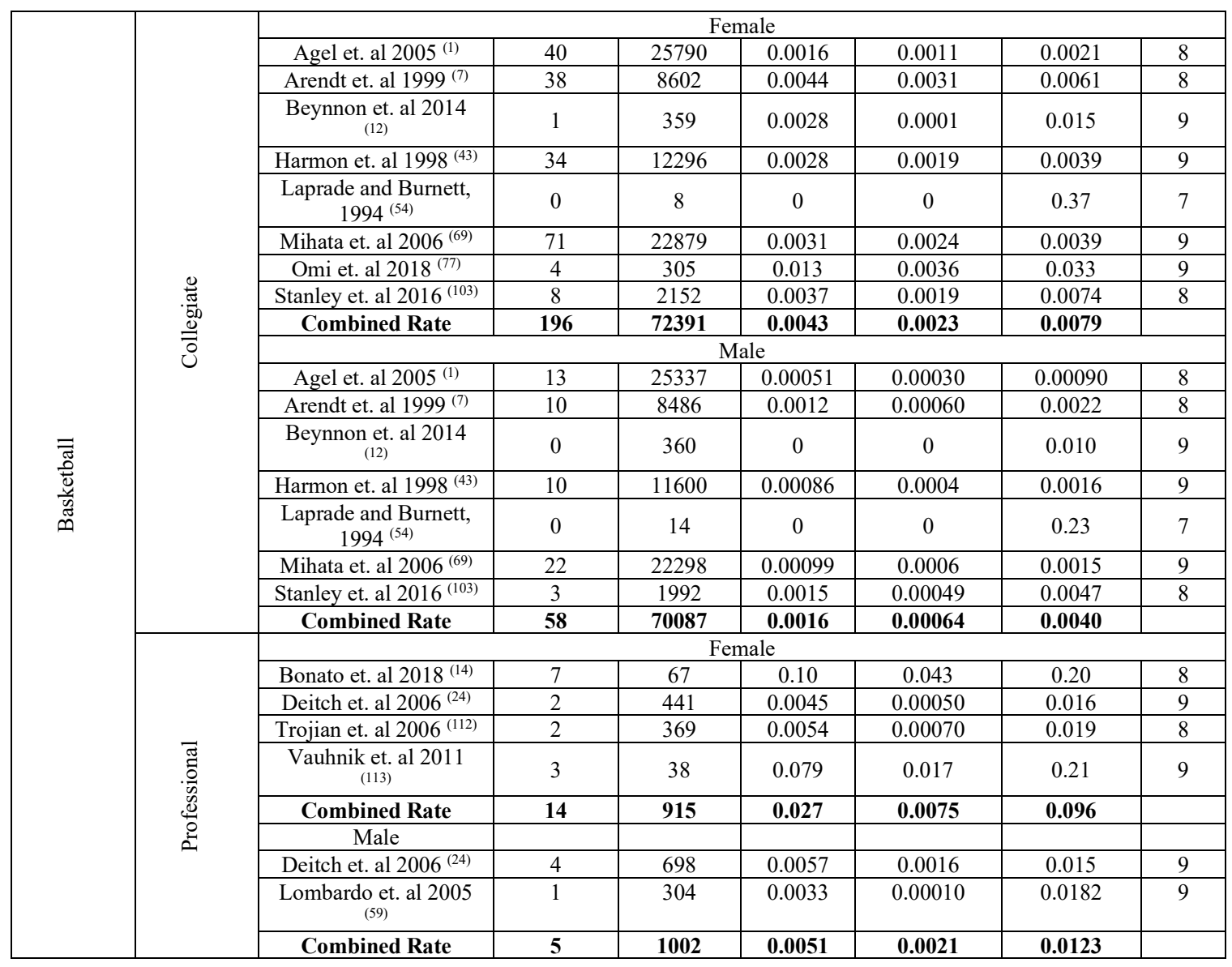

\begin{tabular}{|c|c|c|c|c|c|c|c|c|}
\hline \multirow{4}{*}{ 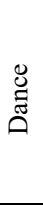 } & \multirow{4}{*}{ 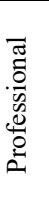 } & \multicolumn{7}{|c|}{ Female } \\
\hline & & $\begin{array}{c}\text { Liederbach et. al } \\
2008^{(58)}\end{array}$ & 2 & 117 & 0.018 & 0.0021 & 0.060 & 9 \\
\hline & & \multicolumn{7}{|c|}{ Male } \\
\hline & & $\begin{array}{c}\text { Liederbach et. al } \\
2008^{(58)}\end{array}$ & 0 & 62 & 0 & 0 & 0.058 & 9 \\
\hline
\end{tabular}

\begin{tabular}{|c|c|c|c|c|c|c|c|c|}
\hline \multirow{4}{*}{ 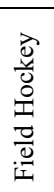 } & \multirow[b]{2}{*}{$\begin{array}{l}\text { High } \\
\text { School }\end{array}$} & \multicolumn{7}{|c|}{ Female } \\
\hline & & $\underset{(12)}{\text { Beynnon et. al } 2014}$ & 1 & 439 & 0.0023 & 0.000058 & 0.013 & 9 \\
\hline & & \multicolumn{7}{|c|}{ Female } \\
\hline & Collegiate & $\underset{(12)}{\operatorname{Beynnon} \text { et. al }} 2014$ & 0 & 132 & $\mathbf{0}$ & $\mathbf{0}$ & 0.028 & 9 \\
\hline
\end{tabular}




\begin{tabular}{|c|c|c|c|c|c|c|c|c|}
\hline $\begin{array}{l}\text { Sport } \\
\text { Type }\end{array}$ & Level & Author (s) \& Year & $\begin{array}{c}\text { Number } \\
\text { of ACLs } \\
\text { Injured } \\
\text { Per } \\
\text { Season }\end{array}$ & $\begin{array}{c}\text { Number } \\
\text { of Non- } \\
\text { Injured } \\
\text { ACLs } \\
\text { per } \\
\text { Season }\end{array}$ & $\begin{array}{c}\text { Injury } \\
\text { Rate }\end{array}$ & $\begin{array}{c}95 \% \\
\text { Confidence } \\
\text { Interval } \\
\text { (LBound) }\end{array}$ & $\begin{array}{c}95 \% \\
\text { Confidence } \\
\text { Interval } \\
\text { (UBound) }\end{array}$ & $\begin{array}{c}\text { Risk } \\
\text { of } \\
\text { Bias }\end{array}$ \\
\hline
\end{tabular}

\begin{tabular}{|c|c|c|c|c|c|c|c|c|}
\hline \multirow{6}{*}{$\begin{array}{l}\overline{\bar{\Xi}} \\
\frac{0}{0} \\
\frac{0}{1} \\
1\end{array}$} & \multirow{4}{*}{ 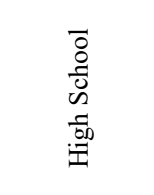 } & \multicolumn{7}{|c|}{ Female } \\
\hline & & Pasanen et. al 2018 & 3 & 72 & 0.042 & 0.0087 & 0.12 & 8 \\
\hline & & \multicolumn{7}{|c|}{ Male } \\
\hline & & 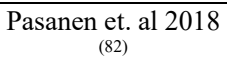 & $\mathbf{0}$ & 111 & $\mathbf{0}$ & $\mathbf{0}$ & 0.033 & 8 \\
\hline & & \multicolumn{7}{|c|}{ Female } \\
\hline & Professional & Pasanen et. al 2008 & 3 & 198 & 0.015 & 0.0031 & 0.04 & 9 \\
\hline
\end{tabular}

\begin{tabular}{|c|c|c|c|c|c|c|c|c|}
\hline \multirow{12}{*}{$\begin{array}{l}\bar{\nabla} \\
\text { है } \\
0 \\
0\end{array}$} & \multirow{7}{*}{ 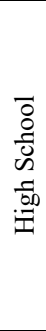 } & \multicolumn{7}{|c|}{ Male } \\
\hline & & Beynnon et. al 2014 & 2 & 1698 & 0.001 & 0.00010 & 0.0042 & 9 \\
\hline & & DeLee et. al $1992^{(25)}$ & 37 & 4362 & 0.0085 & 0.0060 & 0.012 & 9 \\
\hline & & Joseph et. al $2013^{(49)}$ & 57 & 4943 & 0.016 & 0.0087 & 0.015 & 8 \\
\hline & & $\underset{(53)}{\text { Lambson et. al } 1996}$ & 14 & 3305 & 0.0042 & 0.0023 & 0.0071 & 9 \\
\hline & & Meyers et. al 2004 & 3 & 157 & 0.019 & 0.004 & 0.055 & 8 \\
\hline & & Combined Rate & 113 & 14465 & 0.0068 & 0.0032 & 0.014 & \\
\hline & & & & & & & & \\
\hline & & Beynnon et. al 2014 & 1 & 194 & 0.0052 & 0.00010 & 0.028 & 9 \\
\hline & 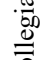 & $\underset{(29)}{\text { Dragoo et. al }} 2012$ & 64 & 312878 & 0.00020 & 0.00020 & 0.00030 & 8 \\
\hline & $\mho$ & 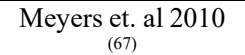 & 17 & 1135 & 0.015 & 0.0087 & 0.024 & 9 \\
\hline & & Combined Rate & 82 & 314207 & 0.0024 & 0.00017 & 0.033 & \\
\hline
\end{tabular}

\begin{tabular}{|c|c|c|c|c|c|c|c|c|}
\hline \multirow{7}{*}{ 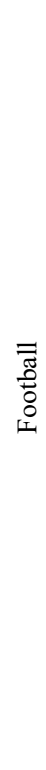 } & \multirow{7}{*}{ 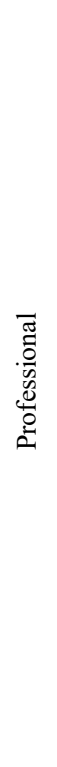 } & \multicolumn{7}{|c|}{ Male } \\
\hline & & $\begin{array}{l}\text { Inclan et. al } \\
\text { 2021 (Study } \\
\text { 1: Mai) } \\
\text { (48) }\end{array}$ & 165 & 18989 & 0.028 & 0.026 & 0.030 & 9 \\
\hline & & $\begin{array}{c}\text { Inclan et. al } \\
2021 \text { (Study } \\
2: \\
\text { Okoroha) }^{(48)}\end{array}$ & 130 & 11364 & 0.031 & 0.028 & 0.034 & 9 \\
\hline & & $\begin{array}{c}\text { Inclan et. al } \\
\text { 2021 (Study } \\
\text { 3:Dodson, } \\
\text { Secrist, Yang) } \\
\text { (48) }\end{array}$ & 219 & 7565 & 0.032 & 0.028 & 0.036 & 9 \\
\hline & & $\begin{array}{c}\text { Inclan et. al } \\
2021 \text { (Study } \\
4: \\
\text { Johnston) } \\
\text { (48) }\end{array}$ & 156 & 5682 & 0.031 & 0.026 & 0.035 & 9 \\
\hline & & $\begin{array}{c}\text { Inclan et. al } \\
2021 \text { (Study } \\
5: \\
\text { Eisenstein) } \\
(48)\end{array}$ & 92 & 3790 & 0.030 & 0.025 & 0.036 & 9 \\
\hline & & $\begin{array}{c}\text { Combined } \\
\text { Rate }\end{array}$ & 762 & 47390 & 0.030 & 0.028 & 0.032 & \\
\hline
\end{tabular}




\begin{tabular}{|c|c|c|c|c|c|c|c|c|}
\hline $\begin{array}{l}\text { Sport } \\
\text { Type }\end{array}$ & Level & $\begin{array}{c}\text { Author (s) \& } \\
\text { Year }\end{array}$ & $\begin{array}{c}\text { Number } \\
\text { of ACLs } \\
\text { Injured } \\
\text { Per } \\
\text { Season }\end{array}$ & $\begin{array}{l}\text { Number } \\
\text { of Non- } \\
\text { Injured } \\
\text { ACLs } \\
\text { per } \\
\text { Season }\end{array}$ & $\begin{array}{c}\text { Injury } \\
\text { Rate }\end{array}$ & $\begin{array}{c}95 \% \\
\text { Confidence } \\
\text { Interval } \\
\text { (LBound) }\end{array}$ & $\begin{array}{c}95 \% \\
\text { Confidence } \\
\text { Interval } \\
\text { (UBound) }\end{array}$ & $\begin{array}{l}\text { Risk } \\
\text { of } \\
\text { Bias }\end{array}$ \\
\hline
\end{tabular}

\begin{tabular}{|c|c|c|c|c|c|c|c|c|}
\hline \multirow{4}{*}{ 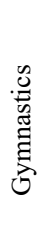 } & \multirow{4}{*}{ 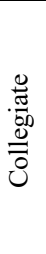 } & \multicolumn{7}{|c|}{ Female } \\
\hline & & $\begin{array}{c}\text { Laprade and } \\
\text { Burnett, } 1994 \\
(54)\end{array}$ & $\mathbf{0}$ & 6 & $\mathbf{0}$ & $\mathbf{0}$ & 0.46 & 7 \\
\hline & & \multicolumn{7}{|c|}{ Male } \\
\hline & & $\begin{array}{c}\text { Laprade and } \\
\text { Burnett, } 1994 \\
(54)\end{array}$ & 0 & 8 & 0 & $\mathbf{0}$ & 0.37 & 7 \\
\hline
\end{tabular}

\begin{tabular}{|c|c|c|c|c|c|c|c|c|}
\hline \multirow{12}{*}{ 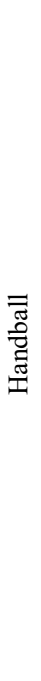 } & \multirow[b]{2}{*}{ High School } & \multicolumn{7}{|c|}{ Female } \\
\hline & & $\begin{array}{c}\text { Oshima et. al } \\
2018^{(78)}\end{array}$ & 4 & 100 & 0.040 & 0.011 & 0.099 & 9 \\
\hline & \multirow[b]{2}{*}{ Collegiate } & Female & & & & & & \\
\hline & & $\begin{array}{l}\text { Petersen et. al } \\
2005^{(84)}\end{array}$ & 5 & 137 & 0.037 & 0.012 & 0.083 & 8 \\
\hline & \multirow{8}{*}{ 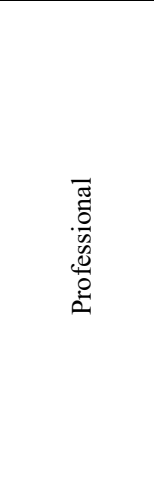 } & \multicolumn{7}{|c|}{ Female } \\
\hline & & $\begin{array}{c}\text { Myklebust et. al } \\
2003 \text { (Year 1) } \\
\text { (74) }\end{array}$ & 29 & 913 & 0.032 & 0.021 & 0.045 & 9 \\
\hline & & $\begin{array}{l}\text { Steffen et. al } \\
2016^{(105)}\end{array}$ & 4 & 416 & 0.0096 & 0.0026 & 0.024 & 8 \\
\hline & & $\begin{array}{c}\text { Vauhnik et. al } \\
2011\end{array}$ & 6 & 252 & 0.024 & 0.0088 & 0.051 & 9 \\
\hline & & $\begin{array}{l}\text { Wedderkopp et. } \\
\text { al } 1997^{(118)}\end{array}$ & 4 & 205 & 0.020 & 0.0053 & 0.049 & 8 \\
\hline & & $\begin{array}{c}\text { Combined } \\
\text { Rate } \\
\end{array}$ & 43 & 1786 & 0.022 & 0.013 & 0.036 & \\
\hline & & \multicolumn{7}{|c|}{ Male } \\
\hline & & $\begin{array}{c}\text { Seil et. al } 1998 \\
(96)\end{array}$ & 4 & 182 & 0.022 & 0.0060 & 0.055 & 7 \\
\hline
\end{tabular}

\begin{tabular}{|c|c|c|c|c|c|c|c|c|}
\hline \multirow{6}{*}{ 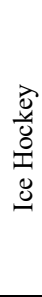 } & \multirow{4}{*}{$\begin{array}{l}\stackrel{0}{\frac{\pi}{0}} \\
\stackrel{0}{0} \\
\stackrel{0}{0}\end{array}$} & \multicolumn{7}{|c|}{ Female } \\
\hline & & $\begin{array}{c}\text { Stanley et. al } \\
2016^{(103)} \\
\end{array}$ & 1 & 1019 & 0.00098 & 0.00014 & 0.0069 & 8 \\
\hline & & \multicolumn{7}{|c|}{ Male } \\
\hline & & $\begin{array}{c}\text { Stanley et. al } \\
2016^{(103)}\end{array}$ & 3 & 2117 & 0.0014 & 0.00046 & 0.0044 & 8 \\
\hline & \multirow[b]{2}{*}{ Professional } & \multicolumn{7}{|c|}{ Male } \\
\hline & & $\begin{array}{l}\text { Longstaffe et. al } \\
2020^{(60)}\end{array}$ & 7 & 2081 & 0.0034 & 0.0014 & 0.0069 & 9 \\
\hline & & & & & & & & \\
\hline \multirow{8}{*}{ 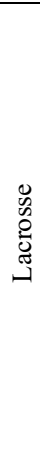 } & \multirow{8}{*}{ 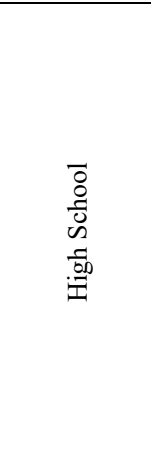 } & \multicolumn{7}{|c|}{ Female } \\
\hline & & $\begin{array}{c}\text { Beynnon et. al } \\
2014^{(12)}\end{array}$ & 2 & 844 & 0.0024 & 0.00030 & 0.0085 & 9 \\
\hline & & $\begin{array}{c}\text { Stanley et. al } \\
2016^{(103)}\end{array}$ & 6 & 564 & 0.011 & 0.0048 & 0.023 & 8 \\
\hline & & $\begin{array}{c}\text { Combined } \\
\text { Rate }\end{array}$ & 8 & 1408 & 0.0056 & 0.0013 & 0.024 & \\
\hline & & \multicolumn{7}{|c|}{ Male } \\
\hline & & $\begin{array}{l}\text { Beynnon et. al } \\
2014^{(12)}\end{array}$ & 2 & 988 & 0.0020 & 0.0002 & 0.0073 & 9 \\
\hline & & $\begin{array}{c}\text { Stanley et. al } \\
2016^{(103)}\end{array}$ & 4 & 606 & 0.0066 & 0.0025 & 0.017 & 8 \\
\hline & & $\begin{array}{c}\text { Combined } \\
\text { Rate }\end{array}$ & 6 & 1594 & 0.0041 & 0.0013 & 0.013 & \\
\hline
\end{tabular}




\begin{tabular}{|c|c|c|c|c|c|c|c|c|}
\hline $\begin{array}{l}\text { Sport } \\
\text { Type }\end{array}$ & Level & Author (s) \& Year & $\begin{array}{c}\text { Number } \\
\text { of ACLs } \\
\text { Injured } \\
\text { Per } \\
\text { Season }\end{array}$ & $\begin{array}{l}\text { Number } \\
\text { of Non- } \\
\text { Injured } \\
\text { ACLs } \\
\text { per } \\
\text { Season }\end{array}$ & $\begin{array}{c}\text { Injury } \\
\text { Rate }\end{array}$ & $\begin{array}{c}95 \% \\
\text { Confidence } \\
\text { Interval } \\
\text { (LBound) }\end{array}$ & $\begin{array}{c}95 \% \\
\text { Confidence } \\
\text { Interval } \\
\text { (UBound) }\end{array}$ & $\begin{array}{c}\text { Risk } \\
\text { of } \\
\text { Bias }\end{array}$ \\
\hline
\end{tabular}

\begin{tabular}{|c|c|c|c|c|c|c|c|c|}
\hline \multirow{10}{*}{ 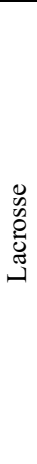 } & \multirow{10}{*}{ 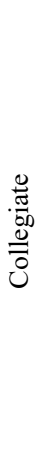 } & \multicolumn{7}{|c|}{ Female } \\
\hline & & 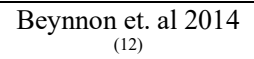 & 1 & 959 & 0.0010 & 0 & 0.0058 & 9 \\
\hline & & Mihata et. al $2006^{(69)}$ & 10 & 26486 & 0.00038 & 0.00020 & 0.00070 & 9 \\
\hline & & $\underset{(103)}{\text { Stanley et. al }} 2016$ & 3 & 1713 & 0.00175 & 0.00056 & 0.0054 & 8 \\
\hline & & Combined Rate & 14 & 29158 & 0.00078 & 0.00026 & 0.0023 & \\
\hline & & \multicolumn{7}{|c|}{ Male } \\
\hline & & 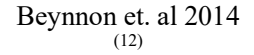 & 2 & 1198 & 0.0017 & 0.00020 & 0.0060 & 9 \\
\hline & & Mihata et. al $2006^{(69)}$ & 11 & 21733 & 0.00051 & 0.00030 & 0.00090 & 9 \\
\hline & & $\underset{(103)}{\text { Stanley et. al }} 2016$ & 2 & 3118 & 0.00064 & 0.00016 & 0.0026 & 8 \\
\hline & & Combined Rate & 15 & 26049 & 0.00066 & 0.00035 & 0.0013 & \\
\hline
\end{tabular}

\begin{tabular}{|c|c|c|c|c|c|c|c|c|}
\hline \multirow{2}{*}{ Netball } & \multirow{2}{*}{ Professional } & \multicolumn{7}{|c|}{ Female } \\
\hline & & Singh et. al $2013^{(99)}$ & 1 & 58 & 0.0014 & 0.00044 & 0.09 & 6 \\
\hline
\end{tabular}

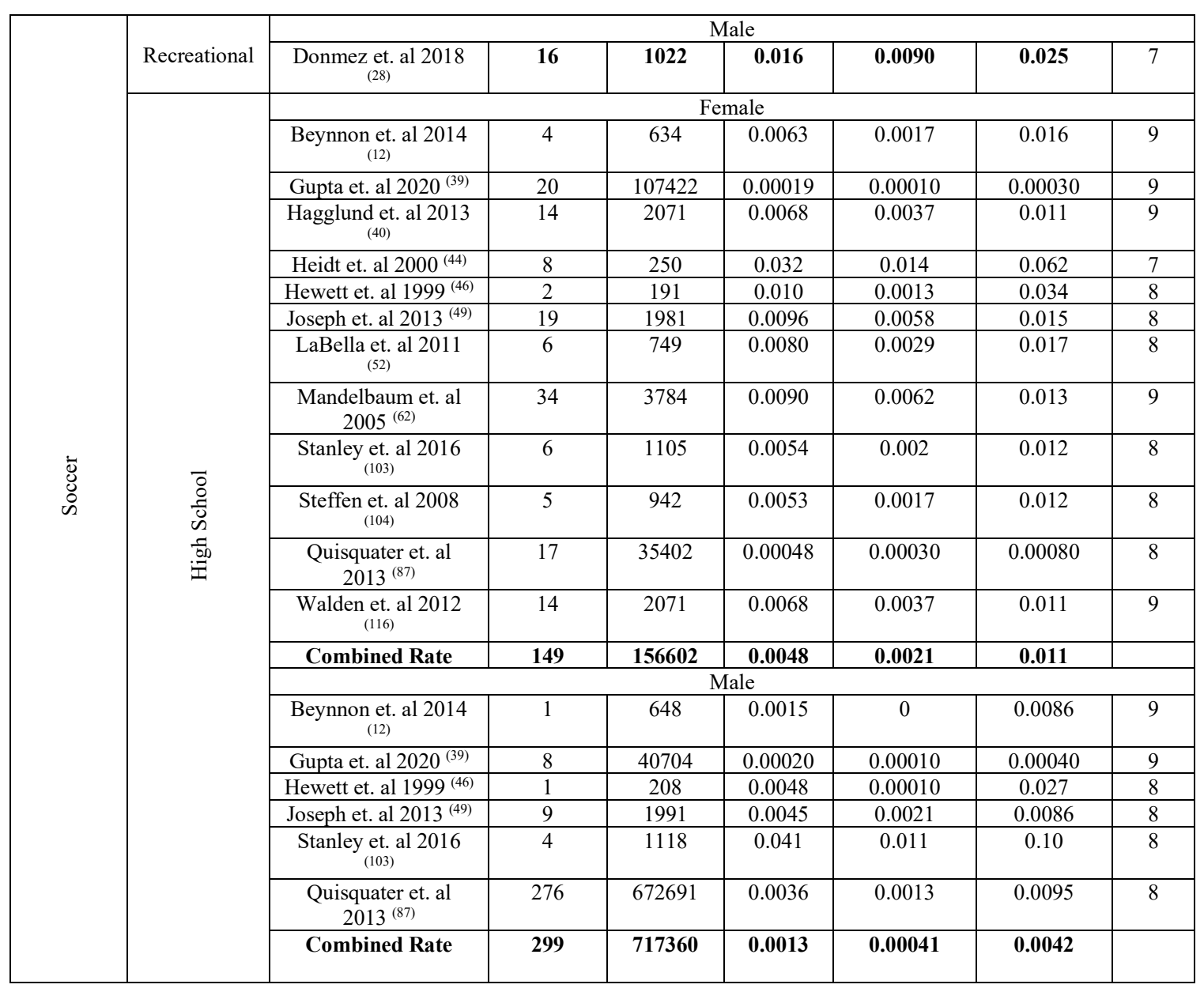




\begin{tabular}{|c|c|c|c|c|c|c|c|c|}
\hline $\begin{array}{l}\text { Sport } \\
\text { Type }\end{array}$ & Level & Author (s) \& Year & $\begin{array}{c}\text { Number } \\
\text { of ACLs } \\
\text { Injured } \\
\text { Per } \\
\text { Season }\end{array}$ & $\begin{array}{l}\text { Number } \\
\text { of Non- } \\
\text { Injured } \\
\text { ACLs } \\
\text { per } \\
\text { Season }\end{array}$ & $\begin{array}{c}\text { Injury } \\
\text { Rate }\end{array}$ & $\begin{array}{c}95 \% \\
\text { Confidence } \\
\text { Interval } \\
\text { (LBound) }\end{array}$ & $\begin{array}{c}95 \% \\
\text { Confidence } \\
\text { Interval } \\
\text { (UBound) }\end{array}$ & $\begin{array}{c}\text { Risk } \\
\text { of } \\
\text { Bias }\end{array}$ \\
\hline
\end{tabular}

\begin{tabular}{|c|c|c|c|c|c|c|c|c|}
\hline & & & & & iale & & & \\
\hline & & Agel et. al $2005^{(1)}$ & 30 & 40301 & 0.00074 & 0.00050 & 0.0011 & 8 \\
\hline & & Arendt et. al $1999^{(7)}$ & 19 & 5263 & 0.0036 & 0.00220 & 0.0056 & 8 \\
\hline & & $\underset{(12)}{\text { Beynnon et. al } 2014}$ & 3 & 586 & 0.0051 & 0.0011 & 0.015 & 9 \\
\hline & & $\underset{(34)}{\text { Gilchrist et. al } 2008}$ & 10 & 842 & 0.012 & 0.0057 & 0.022 & 9 \\
\hline & & Harmon et. al 1998 & 24 & 15839 & 0.0015 & 0.0010 & 0.0023 & 9 \\
\hline & & Howard et. al 2015 & 10 & 382 & 0.026 & 0.013 & 0.048 & 9 \\
\hline & & Meyers et. al 2013 & 4 & 360 & 0.011 & 0.0030 & 0.028 & 9 \\
\hline & & Mihata et. al $2006^{(69)}$ & 58 & 28894 & 0.0020 & 0.0015 & 0.0026 & 9 \\
\hline & & $\underset{(103)}{\text { Stanley et. al }} 2016$ & 11 & 3933 & 0.088 & 0.045 & 0.15 & 8 \\
\hline & $\cdot \frac{\pi}{60}$ & Combined Rate & 169 & 96400 & 0.00611 & 0.00223 & 0.0166 & \\
\hline & 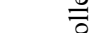 & & & & & & & \\
\hline & $\circlearrowright$ & Agel et. al $2005^{(1)}$ & 15 & 45338 & 0.00033 & 0.00020 & 0.00050 & 8 \\
\hline & & Arendt et. al $1999^{(7)}$ & 16 & 8743 & 0.0018 & 0.0010 & 0.0030 & 8 \\
\hline & & Beynnon et. al 2014 & 2 & 556 & 0.0036 & 0.00040 & 0.013 & 9 \\
\hline & & $\underset{(19)}{\text { Caraffa et. al } 1996}$ & 23 & 277 & 0.083 & 0.053 & 0.12 & 6 \\
\hline & & Harmon et. al 1998 & 15 & 21793 & 0.00069 & 0.00040 & 0.0011 & 9 \\
\hline & & Mihata et. al $2006^{(69)}$ & 28 & 31785 & 0.00088 & 0.00060 & 0.0013 & 9 \\
\hline $\begin{array}{l}0 \\
0\end{array}$ & & $\begin{array}{c}\text { Silvers- } \\
\text { Granelli et. al } \\
2017 \\
(98)\end{array}$ & 16 & 834 & 0.019 & 0.011 & 0.031 & 9 \\
\hline & & $\underset{(103)}{\text { Stanley et. al }} 2016$ & 2 & 2492 & 0.0028 & 0.0016 & 0.0050 & 8 \\
\hline & & Combined Rate & 117 & 111818 & 0.0041 & 0.0019 & 0.0086 & \\
\hline & & & & & iale & & & \\
\hline & & Faude et. al $2006^{(31)}$ & 11 & 132 & 0.083 & 0.042 & 0.14 & 9 \\
\hline & & Faude et. al $2005^{(30)}$ & 11 & 154 & 0.071 & 0.036 & 0.12 & 9 \\
\hline & & Giza et. al $2005^{(35)}$ & 4 & 198 & 0.020 & 0.0055 & 0.051 & 7 \\
\hline & & $\underset{(41)}{\text { Hagglund et. al } 2009}$ & 8 & 220 & 0.036 & 0.016 & 0.070 & 9 \\
\hline & & $\begin{array}{l}\text { Larruskain et. al } \\
2018^{(55)}\end{array}$ & 1 & 34 & 0.029 & 0.00070 & 0.153 & 7 \\
\hline & పే & Le Gall et. al 2008 & 2 & 238 & 0.0084 & 0.0010 & 0.03 & 9 \\
\hline & $\bar{\delta}$ & Nilstad et. al $2014^{(75)}$ & 5 & 168 & 0.030 & 0.0097 & 0.068 & 8 \\
\hline & ڤ & $\begin{array}{l}\text { Ostenberg and Roos, } \\
2000\end{array}$ & 3 & 120 & 0.025 & 0.0052 & 0.071 & 8 \\
\hline & & Padua et. al $2015^{(80)}$ & 1 & 480 & 0.0021 & 0.00010 & 0.012 & 7 \\
\hline & & Roos et. al $1995^{(92)}$ & 106 & 36715 & 0.0029 & 0.0024 & 0.0035 & 9 \\
\hline & & $\underset{(101)}{\text { Soderman et. al } 2000}$ & 1 & 77 & 0.013 & 0.00030 & 0.070 & 7 \\
\hline & & $\underset{(100)}{\text { Soderman et. al } 2001}$ & 5 & 141 & 0.035 & 0.012 & 0.081 & 8 \\
\hline & & $\underset{(105)}{\text { Steffen et. al }} 2016$ & 4 & 443 & 0.0090 & 0.0025 & 0.023 & 8 \\
\hline
\end{tabular}




\begin{tabular}{|c|c|c|c|c|c|c|c|}
\hline & & $\begin{array}{c}\text { Number } \\
\text { Sport } \\
\text { Type }\end{array}$ & Level & Author (s) \& Year & $\begin{array}{c}\text { Number } \\
\text { of Non- } \\
\text { Injured } \\
\text { Injured } \\
\text { ACLs } \\
\text { per } \\
\text { Season }\end{array}$ & $\begin{array}{c}\text { Injury } \\
\text { Rate }\end{array}$ & $\begin{array}{c}\text { C5\% } \\
\text { Confidence } \\
\text { Interval } \\
\text { (LBound) }\end{array}$ \\
$\begin{array}{c}\text { Confidence } \\
\text { Interval } \\
\text { (UBound) }\end{array}$ \\
$\begin{array}{c}\text { (U) Bisk } \\
\text { of } \\
\text { Bias }\end{array}$
\end{tabular}

\begin{tabular}{|c|c|c|c|c|c|c|c|c|}
\hline \multirow{19}{*}{$\begin{array}{l}\dot{\circlearrowright} \\
\text { ঠू } \\
\text { ஜ }\end{array}$} & \multirow{19}{*}{ 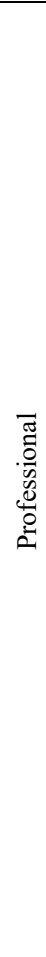 } & \multicolumn{7}{|c|}{ Female } \\
\hline & & $\underset{(110)}{\text { Tegnander et. al }} 2008$ & 2 & 179 & 0.011 & 0.0014 & 0.040 & 8 \\
\hline & & 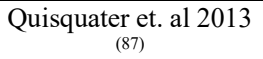 & 3 & 3122 & 0.00096 & 0.00020 & 0.0028 & 8 \\
\hline & & $\underset{(117)}{\text { Walden et. al } 2011}$ & 1 & 309 & 0.0032 & 0.00010 & 0.018 & 7 \\
\hline & & Combined Rate & 168 & 42730 & 0.014 & 0.0073 & 0.027 & \\
\hline & & \multicolumn{7}{|c|}{ Male } \\
\hline & & $\underset{(13)}{\text { Bjorneboe et. al } 2010}$ & 5 & 149 & 0.034 & 0.011 & 0.077 & 8 \\
\hline & & Grassi et. al $2020^{(38)}$ & 12 & 4112 & 0.0029 & 0.0015 & 0.0051 & 9 \\
\hline & & $\underset{(41)}{\text { Hagglund et. al } 2009}$ & 8 & 231 & 0.035 & 0.015 & 0.067 & 9 \\
\hline & & 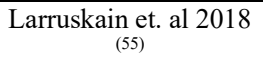 & 0 & 50 & 0 & 0 & 0.071 & 7 \\
\hline & & Padua et. al $2015^{(80)}$ & 0 & 348 & 0 & 0 & 0.011 & 7 \\
\hline & & Rekik et. al $2018^{(89)}$ & 7 & 2236 & 0.0031 & 0.0013 & 0.0064 & 8 \\
\hline & & $\begin{array}{c}\text { Rochcongar et. al } \\
2009^{(90)} \\
\end{array}$ & 58 & 44308 & 0.0013 & 0.0010 & 0.0017 & 8 \\
\hline & & Roi et. al $2006^{(91)}$ & 50 & 429 & 0.12 & 0.088 & 0.015 & 8 \\
\hline & & Roos et. al $1995^{(92)}$ & 232 & 151389 & 0.0015 & 0.0013 & 0.0017 & 9 \\
\hline & & $\begin{array}{c}\text { Schiffner et. al } 2018 \\
(94)\end{array}$ & 9 & 4631 & 0.0019 & 0.00090 & 0.0037 & 8 \\
\hline & & 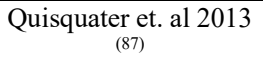 & 49 & 118710 & 0.0041 & 0.00030 & 0.00050 & 8 \\
\hline & & $\underset{(117)}{\text { Walden et. al } 2011}$ & 3 & 2016 & 0.0015 & 0.00030 & 0.0043 & 7 \\
\hline & & Combined Rate & 433 & 328609 & 0.0044 & 0.0016 & 0.012 & \\
\hline
\end{tabular}

\begin{tabular}{|c|c|c|c|c|c|c|c|c|}
\hline \multirow{12}{*}{ 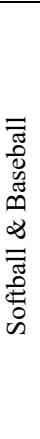 } & \multirow{8}{*}{ 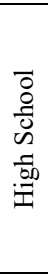 } & \multicolumn{7}{|c|}{ Female } \\
\hline & & Joseph et. al $2013^{(49)}$ & 4 & 1196 & 0.0033 & 0.0013 & 0.0089 & 8 \\
\hline & & Stanley et. al $2016^{(103)}$ & 0 & 2360 & 0 & 0 & 0.0016 & 8 \\
\hline & & Combined Rate & 4 & 3556 & 0.0034 & 0.0014 & 0.0086 & \\
\hline & & \multicolumn{7}{|c|}{ Male } \\
\hline & & Joseph et. al $2013^{(49)}$ & 1 & 1999 & 0.00050 & 0.000070 & 0.0035 & 8 \\
\hline & & Stanley et. al $2016^{(103)}$ & 1 & 2399 & 0.0084 & 0.0012 & 0.057 & 8 \\
\hline & & Combined Rate & 2 & 4398 & 0.0021 & 0.00013 & 0.032 & \\
\hline & \multirow{4}{*}{ 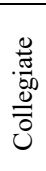 } & \multicolumn{7}{|c|}{ Female } \\
\hline & & Stanley et. al $2016^{(103)}$ & 2 & 2598 & 0.020 & 0.0049 & 0.075 & 8 \\
\hline & & \multicolumn{7}{|c|}{ Male } \\
\hline & & Stanley et. al $2016^{(103)}$ & $\mathbf{0}$ & 1650 & $\mathbf{0}$ & $\mathbf{0}$ & 0.0022 & 8 \\
\hline
\end{tabular}

\begin{tabular}{|c|c|c|c|c|c|c|c|c|}
\hline \multirow{8}{*}{$\frac{\overrightarrow{2}}{200}$} & \multirow[b]{2}{*}{$\begin{array}{l}\text { High } \\
\text { School }\end{array}$} & \multicolumn{7}{|c|}{ Male } \\
\hline & & $\underset{(109)}{\text { Takazawa et. al }} 2016$ & 1 & 289 & 0.0035 & 0.00010 & 0.019 & 9 \\
\hline & \multirow{6}{*}{ 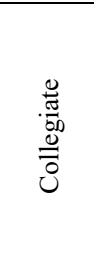 } & \multicolumn{7}{|c|}{ Female } \\
\hline & & $\underset{(12)}{\text { Beynnon et. al } 2014}$ & 2 & 118 & 0.017 & 0.0021 & 0.060 & 9 \\
\hline & & Levy et. al $1997^{(57)}$ & 5 & 805 & 0.0062 & 0.0020 & 0.014 & 9 \\
\hline & & Combined Rate & 7 & 923 & 0.0088 & 0.0034 & 0.023 & \\
\hline & & \multicolumn{7}{|c|}{ Male } \\
\hline & & Beynnon et. al 2014 & 1 & 119 & 0.0084 & 0.00020 & 0.046 & 9 \\
\hline
\end{tabular}




\begin{tabular}{|c|c|c|c|c|c|c|c|c|}
\hline $\begin{array}{l}\text { Sport } \\
\text { Type }\end{array}$ & Level & $\begin{array}{c}\text { Author (s) \& } \\
\text { Year }\end{array}$ & $\begin{array}{c}\text { Number } \\
\text { of ACLs } \\
\text { Injured } \\
\text { Per } \\
\text { Season }\end{array}$ & 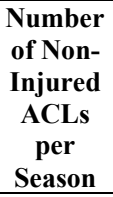 & $\begin{array}{c}\text { Injury } \\
\text { Rate }\end{array}$ & $\begin{array}{c}95 \% \\
\text { Confidence } \\
\text { Interval } \\
\text { (LBound) }\end{array}$ & $\begin{array}{c}95 \% \\
\text { Confidence } \\
\text { Interval } \\
\text { (UBound) }\end{array}$ & $\begin{array}{c}\text { Risk } \\
\text { of } \\
\text { Bias }\end{array}$ \\
\hline \multirow{7}{*}{$\frac{\vec{a}}{200}$} & \multirow{7}{*}{ 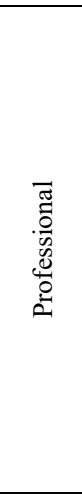 } & \multicolumn{7}{|c|}{ Male } \\
\hline & & $\begin{array}{c}\text { Awwad et. al } \\
2019^{(9)}\end{array}$ & 2 & 58 & 0.0345 & 0.0042 & 0.12 & 7 \\
\hline & & $\begin{array}{c}\text { Brooks et. al } \\
2005 \text { (Part 1) } \\
(16)\end{array}$ & 4 & 542 & 0.0074 & 0.0020 & 0.019 & 8 \\
\hline & & $\begin{array}{c}\text { Brooks et. al } \\
2005 \text { (Part 2) } \\
(17)\end{array}$ & 1 & 501 & 0.0020 & 0.00010 & 0.011 & 8 \\
\hline & & $\begin{array}{c}\text { Dallalana et. al } \\
2007^{(21)}\end{array}$ & 4 & 542 & 0.0074 & 0.0020 & 0.019 & 8 \\
\hline & & $\begin{array}{c}\text { Takazawa et. al } \\
2016^{(109)}\end{array}$ & 1 & 93 & 0.011 & 0.00030 & 0.059 & 9 \\
\hline & & $\begin{array}{c}\text { Combined } \\
\text { Rate }\end{array}$ & 12 & 1736 & 0.0089 & 0.0044 & 0.018 & \\
\hline
\end{tabular}

\begin{tabular}{|c|c|c|c|c|c|c|c|c|}
\hline \multirow{10}{*}{$\begin{array}{l}\overline{\bar{\varpi}} \\
\text { 交 } \\
\overline{0} \\
>\end{array}$} & \multirow{4}{*}{$\begin{array}{l}\overline{8} \\
\overline{0} \\
0 \\
0 \\
\overrightarrow{0} \\
\overrightarrow{00} \\
\overrightarrow{0}\end{array}$} & \multicolumn{7}{|c|}{ Female } \\
\hline & & $\begin{array}{c}\text { Hewett et. al } \\
1999^{(46)}\end{array}$ & 0 & 81 & 0 & 0 & 0.045 & 8 \\
\hline & & $\begin{array}{c}\text { Joseph et. al } \\
2013^{(49)}\end{array}$ & 4 & 1496 & 0.0027 & 0.00070 & 0.0068 & 8 \\
\hline & & $\begin{array}{c}\text { Combined } \\
\text { Rate }\end{array}$ & 4 & 1577 & 0.0029 & 0.0012 & 0.0074 & \\
\hline & \multirow[b]{2}{*}{ Collegiate } & \multicolumn{7}{|c|}{ Female } \\
\hline & & $\begin{array}{c}\text { Beynnon et. al } \\
2014^{(12)}\end{array}$ & 0 & 45 & 0 & 0 & 0.079 & 9 \\
\hline & \multirow{4}{*}{ 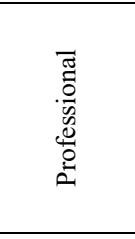 } & \multicolumn{7}{|c|}{ Female } \\
\hline & & $\begin{array}{c}\text { Devetag et. al } \\
2018^{(26)}\end{array}$ & 7 & 1481 & 0.0047 & 0.0019 & 0.0097 & 8 \\
\hline & & $\begin{array}{c}\text { Vauhnik et. al } \\
2011^{(113)}\end{array}$ & 3 & 283 & 0.011 & 0.0022 & 0.031 & 9 \\
\hline & & $\begin{array}{c}\text { Combined } \\
\text { Rate }\end{array}$ & 10 & 1764 & 0.0063 & 0.0030 & 0.013 & \\
\hline \multirow[b]{2}{*}{ Wrestling } & \multirow[b]{2}{*}{$\begin{array}{l}\text { High } \\
\text { School }\end{array}$} & \multicolumn{7}{|c|}{ Male } \\
\hline & & $\begin{array}{l}\text { Joseph et. al } \\
20133^{(49)}\end{array}$ & 5 & 3495 & 0.0014 & 0.00047 & 0.0033 & 8 \\
\hline
\end{tabular}

\section{Table A.1.1: Data extracted from each study}




\section{A.2 Table of the Results/Scores of the Risk of Bias Assessment}

\begin{tabular}{|c|c|c|c|c|c|c|c|c|c|c|}
\hline Study (y) & 1 & 2 & 3 & 4 & 5 & 6 & 7 & 8 & 9 & Total \\
\hline $\begin{array}{l}\text { Agel et. al } \\
2005 \text { (1) }\end{array}$ & Yes & Yes & Yes & Yes & Yes & Yes & Yes & Yes & Unclear & 8 \\
\hline $\begin{array}{l}\text { Arendt et. al } \\
1999(7)\end{array}$ & Yes & Yes & Yes & Yes & Yes & Yes & Yes & Yes & No & 8 \\
\hline $\begin{array}{l}\text { Awwad et. } \\
\text { al } 2019 \text { (9) }\end{array}$ & Yes & Yes & No & Yes & Yes & Yes & Yes & Yes & Unclear & 7 \\
\hline $\begin{array}{l}\text { Beynnon et. } \\
\text { al } 2014 \text { (12) }\end{array}$ & Yes & Yes & Yes & Yes & Yes & Yes & Yes & Yes & Yes & 9 \\
\hline $\begin{array}{l}\text { Bjorneboe } \\
\text { et. al } 2010 \\
\text { (13) }\end{array}$ & Yes & Yes & Yes & Yes & Yes & Yes & Yes & Yes & Unclear & 8 \\
\hline $\begin{array}{l}\text { Bonato et. al } \\
2018 \text { (14) }\end{array}$ & Yes & Yes & Unclear & Yes & Yes & Yes & Yes & Yes & Yes & 8 \\
\hline $\begin{array}{l}\text { Brooks et. al } \\
2005 \text { (Part 1) } \\
\text { (16) }\end{array}$ & Yes & Yes & No & Yes & Yes & Yes & Yes & Yes & Yes & 8 \\
\hline $\begin{array}{l}\text { Brooks et. al } \\
2005 \text { (Part 2) } \\
\text { (17) }\end{array}$ & Yes & Yes & No & Yes & Yes & Yes & Yes & Yes & Yes & 8 \\
\hline $\begin{array}{l}\text { Caraffa et. al } \\
1996 \text { (19) }\end{array}$ & Yes & Unclear & Yes & Yes & Yes & Yes & Yes & No & Unclear & 6 \\
\hline $\begin{array}{l}\text { Dallalana et. } \\
\text { al } 2007(21)\end{array}$ & Yes & Yes & No & Yes & Yes & Yes & Yes & Yes & Yes & 8 \\
\hline $\begin{array}{l}\text { Deitch et. al } \\
2006(24)\end{array}$ & Yes & Yes & Yes & Yes & Yes & Yes & Yes & Yes & Yes & 9 \\
\hline $\begin{array}{l}\text { DeLee et. al } \\
1992(25)\end{array}$ & Yes & Yes & Yes & Yes & Yes & Yes & Yes & Yes & Yes & 9 \\
\hline $\begin{array}{l}\text { Devetag et. } \\
\text { al } 2018 \text { (26) }\end{array}$ & Yes & Yes & Yes & Yes & Yes & No & Yes & Yes & Yes & 8 \\
\hline $\begin{array}{l}\text { Donmez et. } \\
\text { al } 2018 \text { (28) }\end{array}$ & Yes & Yes & Yes & Yes & Yes & Yes & Unclear & Yes & No & 7 \\
\hline $\begin{array}{l}\text { Dragoo et. al } \\
2012(29) \\
\end{array}$ & Yes & Yes & Yes & Yes & Yes & Yes & Yes & Yes & No & 8 \\
\hline $\begin{array}{l}\text { Faude et. al } \\
2006(31) \\
\end{array}$ & Yes & Yes & Yes & Yes & Yes & Yes & Yes & Yes & Yes & 9 \\
\hline $\begin{array}{l}\text { Faude et. al } \\
2005(30)\end{array}$ & Yes & Yes & Yes & Yes & Yes & Yes & Yes & Yes & Yes & 9 \\
\hline $\begin{array}{l}\text { Gilchrist et. } \\
\text { al } 2008 \text { (34) }\end{array}$ & Yes & Yes & Yes & Yes & Yes & Yes & Yes & Yes & Yes & 9 \\
\hline $\begin{array}{l}\text { Giza et. al } \\
2005 \text { (35) }\end{array}$ & Yes & Yes & No & Yes & Yes & Yes & Yes & Yes & Unclear & 7 \\
\hline $\begin{array}{l}\text { Gomez et. al } \\
1996 \text { (36) }\end{array}$ & Yes & Yes & Yes & Yes & Yes & Yes & Yes & Yes & Yes & 9 \\
\hline $\begin{array}{l}\text { Grassi et. al } \\
2020(38)\end{array}$ & Yes & Yes & Yes & Yes & Yes & Yes & Yes & Yes & Yes & 9 \\
\hline
\end{tabular}




\begin{tabular}{|c|c|c|c|c|c|c|c|c|c|c|}
\hline $\begin{array}{l}\text { Gupta et. al } \\
2020^{(39)}\end{array}$ & Yes & Yes & Yes & Yes & Yes & Yes & Yes & Yes & Yes & 9 \\
\hline $\begin{array}{l}\text { Haida et. al } \\
2016(42)\end{array}$ & Yes & Yes & Yes & Yes & Yes & Unclear & Unclear & Yes & Yes & 7 \\
\hline $\begin{array}{l}\text { Hagglund et. } \\
\text { al } 2013 \text { (40) }\end{array}$ & Yes & Yes & Yes & Yes & Yes & Yes & Yes & Yes & Yes & 9 \\
\hline $\begin{array}{l}\text { Hagglund et. } \\
\text { al } 2009 \text { (41) }\end{array}$ & Yes & Yes & Yes & Yes & Yes & Yes & Yes & Yes & Yes & 9 \\
\hline $\begin{array}{l}\text { Harmon et. } \\
\text { al } 1998 \text { (43) }\end{array}$ & Yes & Yes & Yes & Yes & Yes & Yes & Yes & Yes & Yes & 9 \\
\hline $\begin{array}{l}\text { Heidt et. al } \\
2000(44)\end{array}$ & Yes & Yes & No & Yes & Yes & Yes & Yes & Yes & Unclear & 7 \\
\hline $\begin{array}{l}\text { Hewett et. al } \\
1999(46)\end{array}$ & Yes & Yes & No & Yes & Yes & Yes & Yes & Yes & Yes & 8 \\
\hline $\begin{array}{l}\text { Howard et. } \\
\text { al } 2015 \text { (47) }\end{array}$ & Yes & Yes & Yes & Yes & Yes & Yes & Yes & Yes & Yes & 9 \\
\hline $\begin{array}{l}\text { Inclan et. al } \\
2021 \text { (48) }\end{array}$ & Yes & Yes & Yes & Yes & Yes & Yes & Yes & Yes & Yes & 9 \\
\hline $\begin{array}{l}\text { Joseph et. al } \\
2013 \text { (49) }\end{array}$ & Yes & Yes & Yes & Yes & Yes & Yes & Yes & Yes & Unclear & 8 \\
\hline $\begin{array}{l}\text { LaBella et. } \\
\text { al } 2011 \text { (52) }\end{array}$ & Yes & Yes & No & Yes & Yes & Yes & Yes & Yes & Yes & 8 \\
\hline $\begin{array}{l}\text { Lambson et. } \\
\text { al } 1996(53)\end{array}$ & Yes & Yes & Yes & Yes & Yes & Yes & Yes & Yes & Unclear & 8 \\
\hline $\begin{array}{l}\text { Laprade and } \\
\text { Burnett, } \\
1994(54)\end{array}$ & Yes & Yes & No & Yes & Yes & Yes & Yes & Yes & Unclear & 7 \\
\hline $\begin{array}{l}\text { Larruskain } \\
\text { et. al } 2018 \\
(55)\end{array}$ & Yes & Yes & No & Yes & Yes & Yes & Yes & Yes & Unclear & 7 \\
\hline $\begin{array}{l}\text { Le Gall et. al } \\
2008(56)\end{array}$ & Yes & Yes & Yes & Yes & Yes & Yes & Yes & Yes & Yes & 9 \\
\hline $\begin{array}{l}\text { Levy et. al } \\
1997 \text { (57) }\end{array}$ & Yes & Yes & Yes & Yes & Yes & Yes & Yes & Yes & Yes & 9 \\
\hline $\begin{array}{l}\text { Liederbach } \\
\text { et. al } 2008 \\
(58)\end{array}$ & Yes & Yes & Yes & Yes & Yes & Yes & Yes & Yes & Yes & 9 \\
\hline $\begin{array}{l}\text { Lombardo } \\
\text { et. al } 2005 \\
(59)\end{array}$ & Yes & Yes & Yes & Yes & Yes & Yes & Yes & Yes & Yes & 9 \\
\hline $\begin{array}{l}\text { Longstaffe } \\
\text { et. al } 2020 \\
(60)\end{array}$ & Yes & Yes & Yes & Yes & Yes & Yes & Yes & Yes & Yes & 9 \\
\hline $\begin{array}{l}\text { Mandelbaum } \\
\text { et. al } 2005 \\
(62)\end{array}$ & Yes & Yes & Yes & Yes & Yes & Yes & Yes & Yes & Yes & 9 \\
\hline $\begin{array}{l}\text { Messina et. } \\
\text { al } 1999(64)\end{array}$ & Yes & Yes & Yes & Yes & Yes & Yes & Yes & Yes & Yes & 9 \\
\hline $\begin{array}{l}\text { Meyers et. al } \\
2004(66)\end{array}$ & Yes & Yes & Yes & Yes & Yes & Yes & Yes & Yes & Unclear & 8 \\
\hline $\begin{array}{l}\text { Meyers et. al } \\
2010(67)\end{array}$ & Yes & Yes & Yes & Yes & Yes & Yes & Yes & Yes & Yes & 9 \\
\hline
\end{tabular}




\begin{tabular}{|c|c|c|c|c|c|c|c|c|c|c|}
\hline $\begin{array}{l}\text { Meyers et. al } \\
2013(68)\end{array}$ & Yes & Yes & Yes & Yes & Yes & Yes & Yes & Yes & Yes & 9 \\
\hline $\begin{array}{l}\text { Mihata et. al } \\
2006(69)\end{array}$ & Yes & Yes & Yes & Yes & Yes & Yes & Yes & Yes & Yes & 9 \\
\hline $\begin{array}{l}\text { Myklebust } \\
\text { et. al 2003 } \\
\text { (Year 1) } \\
\text { (74) }\end{array}$ & Yes & Yes & Yes & Yes & Yes & Yes & Yes & Yes & Yes & 9 \\
\hline $\begin{array}{l}\text { Nilstad et. al } \\
2014(75)\end{array}$ & Yes & Yes & No & Yes & Yes & Yes & Yes & Yes & Yes & 8 \\
\hline $\begin{array}{l}\text { Omi et. al } \\
2018(77)\end{array}$ & Yes & Yes & Yes & Yes & Yes & Yes & Yes & Yes & Yes & 9 \\
\hline $\begin{array}{l}\text { Oshima et. } \\
\text { al } 2018 \text { (78) }\end{array}$ & Yes & Yes & Yes & Yes & Yes & Yes & Yes & Yes & Yes & 9 \\
\hline $\begin{array}{l}\text { Ostenberg } \\
\text { and Roos, } \\
2000(79)\end{array}$ & Yes & Yes & No & Yes & Yes & Yes & Yes & Yes & Yes & 8 \\
\hline $\begin{array}{l}\text { Padua et. al } \\
2015(80)\end{array}$ & Yes & Unclear & No & Yes & Yes & Yes & Yes & Yes & Yes & 7 \\
\hline $\begin{array}{l}\text { Pasanen et. } \\
\text { al } 2018 \text { (82) }\end{array}$ & Yes & Yes & No & Yes & Yes & Yes & Yes & Yes & Yes & 8 \\
\hline $\begin{array}{l}\text { Pasanen et, } \\
\text { al } 2008(83)\end{array}$ & Yes & Yes & Yes & Yes & Yes & Yes & Yes & Yes & Yes & 9 \\
\hline $\begin{array}{l}\text { Petersen et. } \\
\text { al } 2005(84)\end{array}$ & Yes & Yes & No & Yes & Yes & Yes & Yes & Yes & Yes & 8 \\
\hline $\begin{array}{l}\text { Pujol et. al } \\
2007 \text { (86) }\end{array}$ & Yes & Yes & Yes & Yes & Yes & Yes & Yes & Yes & Unclear & 8 \\
\hline $\begin{array}{l}\text { Raschner et. } \\
\text { al } 2012(88)\end{array}$ & Yes & Yes & Yes & Yes & Yes & Yes & Yes & Yes & Unclear & 8 \\
\hline $\begin{array}{l}\text { Rekik et. al } \\
2018 \text { (89) }\end{array}$ & Yes & Yes & Yes & Yes & Yes & Yes & Yes & Yes & Unclear & 8 \\
\hline $\begin{array}{l}\text { Rochcongar } \\
\text { et. al } 2009 \\
(90)\end{array}$ & Yes & Yes & Yes & Yes & Yes & Yes & Yes & Yes & Unclear & 8 \\
\hline $\begin{array}{l}\text { Roi et. al } \\
2006(91)\end{array}$ & Yes & Yes & Yes & Yes & Yes & Yes & Yes & Yes & Unclear & 8 \\
\hline $\begin{array}{l}\text { Roos et. al } \\
1995(92)\end{array}$ & Yes & Yes & Yes & Yes & Yes & Yes & Yes & Yes & Yes & 9 \\
\hline $\begin{array}{l}\text { Scranton et. } \\
\text { al } 1997(95)\end{array}$ & Yes & Yes & Yes & Yes & Yes & Yes & Yes & Yes & Yes & 9 \\
\hline $\begin{array}{l}\text { Seil et. al } \\
1998(96)\end{array}$ & Yes & Yes & No & Yes & Yes & Yes & Yes & Yes & Unclear & 7 \\
\hline $\begin{array}{l}\text { Silvers- } \\
\text { Granelli et. } \\
\text { al } 2017 \text { (98) }\end{array}$ & Yes & Yes & Yes & Yes & Yes & Yes & Yes & Yes & Yes & 9 \\
\hline $\begin{array}{l}\text { Singh et. al } \\
2013(99)\end{array}$ & Yes & Yes & No & Yes & Yes & No & No & Yes & Yes & 6 \\
\hline $\begin{array}{l}\text { Soderman et. } \\
\text { al } 2000 \\
(101)\end{array}$ & Yes & Yes & No & Yes & Yes & Yes & Yes & Yes & No & 7 \\
\hline
\end{tabular}




\begin{tabular}{|l|l|l|l|l|l|l|l|l|l|l|}
\hline $\begin{array}{l}\text { Soderman et. } \\
\text { al 2001 } \\
(100)\end{array}$ & Yes & Yes & No & Yes & Yes & Yes & Yes & Yes & Yes & 8 \\
\hline $\begin{array}{l}\text { Stanley et. al } \\
2016(103)\end{array}$ & Yes & Yes & Yes & Yes & Yes & Yes & Yes & Yes & Unclear & 8 \\
\hline $\begin{array}{l}\text { Steffen et. al } \\
2008(104)\end{array}$ & Yes & Yes & No & Yes & Yes & Yes & Yes & Yes & Yes & 8 \\
\hline $\begin{array}{l}\text { Steffen et. al } \\
\text { 2016 }(105)\end{array}$ & Yes & Yes & Yes & Yes & Yes & Yes & Yes & Yes & Unclear & 8 \\
\hline $\begin{array}{l}\text { Takazawa et. } \\
\text { al 2016 } \\
(109)\end{array}$ & Yes & Yes & Yes & Yes & Yes & Yes & Yes & Yes & Yes & 9 \\
\hline $\begin{array}{l}\text { Tegnander } \\
\text { et. al 2007 } \\
(110)\end{array}$ & Yes & Yes & No & Yes & Yes & Yes & Yes & Yes & Yes & 8 \\
\hline $\begin{array}{l}\text { Trojian et. al } \\
2006(112)\end{array}$ & Yes & Yes & No & Yes & Yes & Yes & Yes & Yes & Yes & 8 \\
\hline $\begin{array}{l}\text { Quisquater } \\
\text { et. al } \\
2013(87)\end{array}$ & Yes & Yes & Yes & Yes & Yes & Yes & Yes & Yes & Unclear & 8 \\
\hline $\begin{array}{l}\text { Viola et. al } \\
1999(115)\end{array}$ & Yes & Yes & Yes & Yes & Yes & Yes & Yes & Yes & Yes & 9 \\
\hline
\end{tabular}

Table A.2.1: Results of the Risk of Bias Assessment Using the Joanna Briggs Institute Critical Appraisal tools for use in JBI Systematic Reviews 


\section{A.3 Figure of the JBI Critical Appraisal Checklist}

\section{(अ) \\ THE JOANNA BRIGGS INSTITUTE \\ JBI Critical Appraisal Checklist for Studies Reporting Prevalence Data}

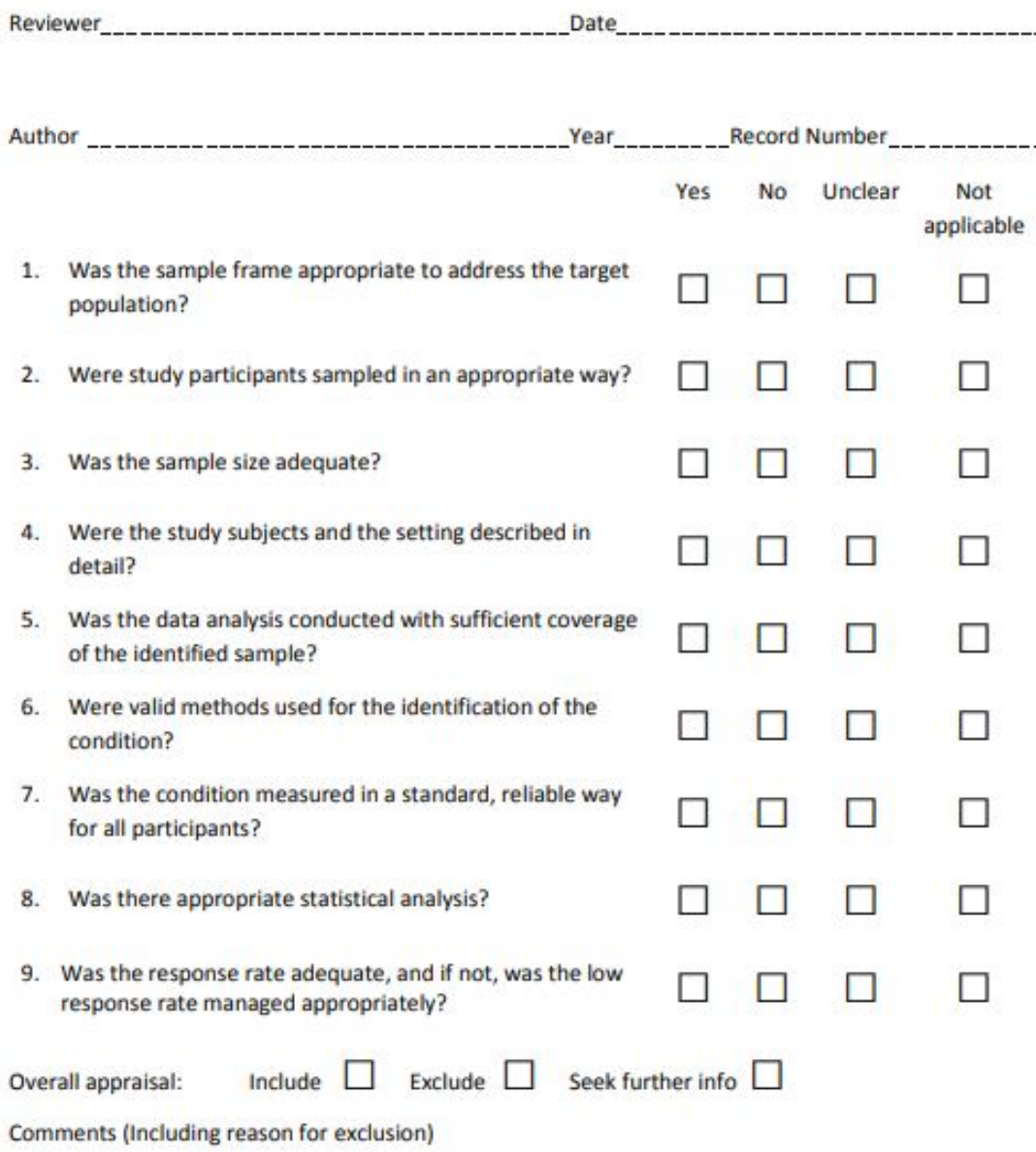

1. Was the sample frame appropriate to address the target population?

2. Were study participants sampled in an appropriate way?

3. Was the sample size adequate?

4. Were the study subjects and the setting described in detail?

5. Was the data analysis conducted with sufficient coverage of the identified sample?

6. Were valid methods used for the identification of the condition?

7. Was the condition measured in a standard, reliable way for all participants?

8. Was there appropriate statistical analysis?

9. Was the response rate adequate, and if not, was the low response rate managed appropriately?

Overall appraisal: $\quad$ Include $\square$ Exclude $\square$ Seek further info

Comments (Including reason for exclusion)

Figure A.3.1: JBI Critical Appraisal Checklist for Studies Reporting Prevalence Data

Figure A.3.2: JBI Critical Appraisal Checklist for Studies Reporting Prevalence Data 